\title{
5,10b-Ethanophenanthridine Amaryllidaceae Alkaloids Inspire the Discovery of Novel Bicyclic Ring Systems with Activity Against Drug Resistant Cancer Cells $\uparrow$
}

Sean Henry, ${ }^{a}$ Ria Kidner, ${ }^{\text {a }}$ Mary R. Reisenauer, ${ }^{\mathrm{a}}$ Igor V. Magedov, ${ }^{\mathrm{a}}$ Ria Quintana, ${ }^{\mathrm{a}}$ Robert Kiss, ${ }^{\mathrm{b}}$ Véronique Mathieu, ${ }^{\mathrm{b}}$ Florence Lefranc, ${ }^{\mathrm{c}}$ Ramesh Dasari, ${ }^{\mathrm{d}}$ Antonio Evidente, ${ }^{\mathrm{e}}$ Xiaojie Yu, ${ }^{\mathrm{f}}$ Xiuye Ma,${ }^{\mathrm{f}}$ Alexander Pertsemlidis, ${ }^{\mathrm{f}}$ Regina Cencic, ${ }^{\mathrm{g}}$ Jerry Pelletier, ${ }^{\mathrm{g}}$ David A. Cavazos, ${ }^{\mathrm{h}}$ Andrew J. Brenner, ${ }^{\mathrm{h}}$ Alexander V. Aksenov, ${ }^{\text {S Snezna }}$ Rogelj, ${ }^{\text {a }}$ Alexander Kornienko, ${ }^{\mathrm{d},{ }^{*}}$ and Liliya V. Frolova ${ }^{\mathrm{a},{ }^{*}}$

${ }^{a}$ Departments of Chemistry and Biology, New Mexico Institute of Mining and Technology, Socorro, NM 87801, USA

${ }^{b}$ Laboratoire de Cancérologie et de Toxicologie Expérimentale, Faculté de Pharmacie, Université Libre de Bruxelles (ULB), Campus de la Plaine, CP205/1, Boulevard du Triomphe, Brussels, Belgium

${ }^{c}$ Service de Neurochirurgie, Hôpital Erasme, ULB, 808 route de Lennik, 1070 Brussels, Belgium

${ }^{d}$ Department of Chemistry and Biochemistry, Texas State University, San Marcos, TX 78666, USA

${ }^{e}$ Dipartimento di Scienze Chimiche, Universita' di Napoli Federico II, Complesso Universitario Monte Sant'Angelo, Via Cintia 4, 80126 Napoli, Italy 
${ }^{f}$ Greehey Children's Cancer Research Institute, UT Health Science Center at San Antonio, 8403 Floyd Curl Drive, San Antonio, TX 78229, USA

${ }^{g}$ Department of Biochemistry, McGill University, Montreal, QC H3G 1Y6, Canada

${ }^{h}$ Cancer Therapy and Research Center, The University of Texas Health Science Center at San Antonio, 7703 Floyd Curl Drive, San Antonio, Texas 78229, USA

${ }^{i}$ Department of Chemistry, North Caucasus University, la Pushkin St., Stavropol 355009, Russian Federation

* Corresponding authors. Email addresses: a_k76@txstate.edu (A. Kornienko); lfrolova@nmt.edu (L. Frolova).

$\dagger$ This manuscript is dedicated to Prof. Yuri I. Smushkevich on the occasion of his $80^{\text {th }}$ birthday.

\section{Abstract}

Plants of the Amaryllidaceae family produce a large variety of alkaloids and non-basic secondary metabolites, many of which are investigated for their promising anticancer activities. Of these, crininetype alkaloids based on the 5,10b-ethanophenanthridine ring system were recently shown to be effective at inhibiting proliferation of cancer cells resistant to various pro-apoptotic stimuli and representing tumors with dismal prognoses refractory to current chemotherapy, such as glioma, melanoma, non-small-cell lung, esophageal, head and neck cancers, among others. Using this discovery as a starting point and taking advantage of a concise biomimetic route to the crinine skeleton, a collection of crinine analogues were synthetically prepared and evaluated against cancer 
cells. The compounds exhibited single-digit micromolar activities and retained this activity in a variety of drug-resistant cancer cell cultures. This investigation resulted in the discovery of new bicyclic ring systems with significant potential in the development of effective clinical cancer drugs capable of overcoming cancer chemotherapy resistance.

\section{Keywords}

Glioblastoma; apoptosis resistance; multidrug resistance; translation inhibition; lycorine; haemanthamine

\section{Abbreviations}

ATCC, American Type Culture Collection; DAPI, 4',6-diamidino-2-phenylindole; DMEM, Dulbecco's modified Eagle's medium; DMF, dimethylformamide; DMSO, dimethyl sulfoxide; DSMZ, Deutsche Sammlung von Mikroorganismen and Zellkulturen; ECACC, European Collection of Cell Culture; EGFR, epidermal growth factor receptor; FBS, fetal bovine serum; GBM, glioblastoma multiforme; HRMS, high resolution mass spectrometry; MGMT, $\mathrm{O}^{6}$-methylguanine-DNAmethyltransferase; MDR, multidrug resistance; MTT, 3-(4,5-dimethylthiazol-2-yl)-2,5diphenyltetrazolium bromide; NSCLC, non-small cell lung cancer; PAO, phenyl arsine oxide; P-gp, Pglycoprotein; PODO, podophyllotoxin; SAR, structure-activity relationship; PIFA, phenyliodine (III) bis(trifluoroacetate); TMZ, temozolomide; TMS, tetramethylsilane; TLC, thin layer chromatography; $\mathrm{SD}$, standard deviation. 


\section{Introduction}

Apoptosis resistance is a hallmark of cancer, because defects in apoptosis regulators invariably accompany tumorigenesis and sustain malignant progression. Because most standard chemotherapeutic agents work by inducing apoptosis in cancer cells, ${ }^{1,2}$ its disruption during tumor evolution can promote intrinsic drug resistance and result in therapy failure. For example, one type of cancer with such intrinsic resistance to apoptosis induction is glioblastoma multiforme (GBM). GBM cells are generally highly resistant to many different apoptotic stimuli resulting in low effectiveness of classical proapoptotic therapeutic approaches. ${ }^{3,4}$ Indeed, GBM is characterized by a deregulated tumor genome containing opportunistic deletions of tumor suppressor genes as well as amplification or mutational hyper-activation of receptor tyrosine kinase receptors. ${ }^{5}$ These genetic changes result in enhanced survival pathways and systematic defects in the apoptotic machinery. ${ }^{5}$ As a result, GBM is associated with dismal prognoses ${ }^{4-8}$ and GBM patients have a median survival expectancy of less than 14 months when treated with a standard protocol of surgical resection, radiotherapy and chemotherapy with temozolomide (TMZ). ${ }^{9,10}$ Other apoptosis-resistant cancers include the tumors of the lung, liver, stomach, esophagus, pancreas as well as melanomas, and they are all associated with dismal prognoses. ${ }^{11}$

In addition to intrinsic resistance to chemotherapeutic agents, tumors often develop acquired resistance, in which they are initially susceptible to treatment and patients respond to chemotherapy but then become refractory to a broad spectrum of structurally and mechanistically diverse antitumor agents. This phenomenon, referred to as multidrug resistance (MDR), ${ }^{12,13}$ usually results from upregulation of protein pumps, such as P-glycoprotein (P-gp), leading to the reduction of drug concentration in cancer cells. MDR is one of the major causes of chemotherapy failure, for example with such widely used anticancer drugs as the vinca alkaloids ${ }^{14}$ or the taxanes. ${ }^{15}$ 
In search of medicinal leads capable of combating drug-resistant cancers, we have been investigating small molecule constituents of the Amaryllidaceae plants, whose medicinal value has been recognized for a long time. The use of Amaryllidaceae plants dates back to at least the fourth century BC, when Hippocrates of Cos used oil from the daffodil Narciclasus poeticus L. for the treatment of cancer. ${ }^{16}$ In more recent times, a large number of structurally diverse alkaloids, along with non-basic amidic constituents (isocarbostyrils), possessing a wide spectrum of biological activities have been isolated from the Amaryllidaceae species. ${ }^{17-20}$ A number of these natural products, such as phenanthridines narciclasine, lycorine and so-called crinine-type alkaloids containing a C11,C12 ethylene bridge on the phenanthridine skeleton, such as haemanthamine, haemanthidine and bulbispermine (Figure 1), are of interest due to their promising anticancer properties. ${ }^{21}$ Thus, $^{2}$ narciclasine and lycorine have been actively investigated for their potent anti-tumor effects, both in vitro and in vivo, in various pre-clinical models of human cancers by many research groups, ${ }^{22-30}$ including their evaluation as cytostatic agents active against apoptosis-resistant cancers by us. ${ }^{31-37}$ The antiproliferative activity of the crinine-type alkaloids has also been reported by natural product chemists on numerous occasions. ${ }^{38-44}$ However, despite some dated work reporting the inhibition of protein biosynthesis by crinine-type alkaloids, ${ }^{45}$ the paucity of in-depth biological studies ${ }^{46-48}$ of the anticancer effects of these compounds has led to insufficient attention to these agents from the medicinal chemistry community. We recently showed, however, that these 5,10b-ethanophenanthridine alkaloids, including haemanthamine, haemanthidine and bulbispermine, appear to be as promising in the treatment of apoptosis-resistant cancers as their congeners, narciclasine and lycorine. ${ }^{32,48} \mathrm{We}$ demonstrated that at antiproliferative $\mathrm{GI}_{50}$ doses, these crinine-type alkaloids exhibit non-apoptotic cytostatic effects, while apoptosis induction (in apoptosis-sensitive cell lines) require 5-10 times higher doses. $^{32}$ Furthermore, using bulbispermine as a model crinine-type alkaloid, we demonstrated that these cytostatic effects occur through impairing the actin cytoskeleton organization. ${ }^{48}$ 
This discovery makes the crinine-type alkaloids an excellent starting point for the generation of compounds able to combat cancers, which are naturally resistant to chemotherapy, such as glioblastoma, melanoma, non-small-cell lung cancer (NSCLC), among others. The investigation reported herein describes the generation of a collection of synthetic compounds based on the crininetype 5,10b-ethanophenanthridine skeleton with the aim of obtaining new structural leads with activity against drug-resistant cancer cells.

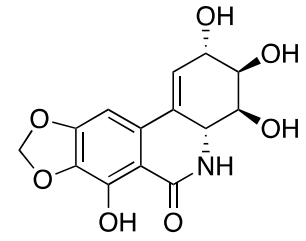

narciclasine

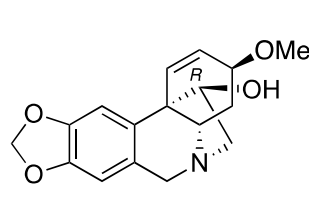

haemanthamine

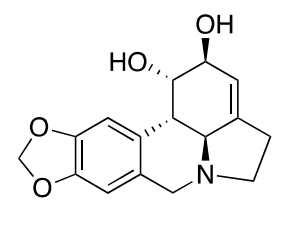

lycorine

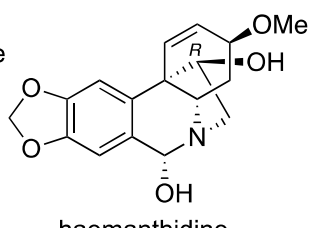

haemanthidine

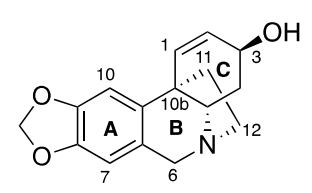

(+)-crinine

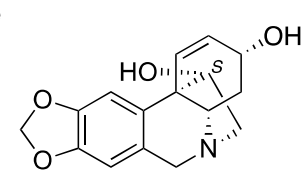

bulbispermine

Figure 1. Structures of selected Amaryllidaceae anticancer constituents

\section{Results and Discussion}

\subsection{Chemistry}

Our synthetic route is based on the use of a biomimetic synthesis of the crinine skeleton. The results of radiotracer experiments revealed that the biosynthesis of the crinine skeleton involves an intramolecular para-para oxidative coupling of $O$-methylnorbelladine with the subsequent intramolecular Michael cyclization to afford noroxomaritidine (Scheme 1). ${ }^{21}$ This oxidative phenolic coupling has been successfully performed in laboratory and the first biomimetic synthesis of the crinine skeleton was achieved using a vanadium oxytrichloride-promoted reaction reported in 1970 by Schwartz and Holton. ${ }^{49}$ More recent modifications of this method involved the reactions utilizing hypervalent iodine to achieve the desired phenolic coupling. Such efforts led to the total syntheses of 
maritidine, ${ }^{49-51}$ siculine, ${ }^{52}$ oxocrinine ${ }^{52}$ epicrinine, ${ }^{52}$ powelline, ${ }^{53}$ and 14,15 -dideoxycripowellin. ${ }^{54}$ Analysis of all published total syntheses of the crinine-type alkaloids reveals that the biomimetic strategy provides the shortest route to these natural products. However, prior to our investigation, it had not been applied to the generation of synthetic analogues with the crinine-like 5,10bethanophenanthridine ring system.
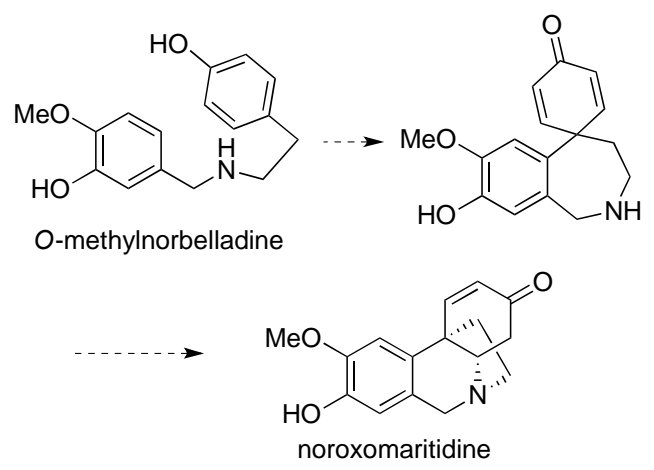

Scheme 1. Biosynthesis of the crinine skeleton

Thus, to utilize this biomimetic approach, ${ }^{52}$ various aromatic aldehydes 1a-l were reacted with tyramine to form imines, which without isolation were reduced with sodium borohydride to the corresponding amines 2a-l (Scheme 2). These were protected as trifluoroacetamides 3a-l and then converted to spirodienones 4a-I upon the oxidative cyclization promoted with phenyliodine (III) bis(trifluoroacetate) (PIFA) in 2,2,2-trifluoroethanol. Removal of the trifluoroacetamide protection led to an intramolecular Michael addition to generate the 5,10b-ethanophenanthridine ring system 5a-l. The structures of the synthesized compounds and reaction yields are given in Table 1 . As can be seen, in all shown examples the key oxidative cyclization of $\mathbf{3} \rightarrow \mathbf{4}$ was highly regioselective with the exception of substrates $\mathbf{3 h}$ and $\mathbf{3 j}$, where mixtures of isomeric spirodienones $\mathbf{4 h} / \mathbf{i}$ and $\mathbf{4 j} / \mathbf{k}$ were obtained. These subsequently gave pure regioisomeric crinine analogues $\mathbf{5 h}$ and $\mathbf{5 i}$ as well as $\mathbf{5} \mathbf{j}$ and $\mathbf{5 k}$, respectively (Table 1). 

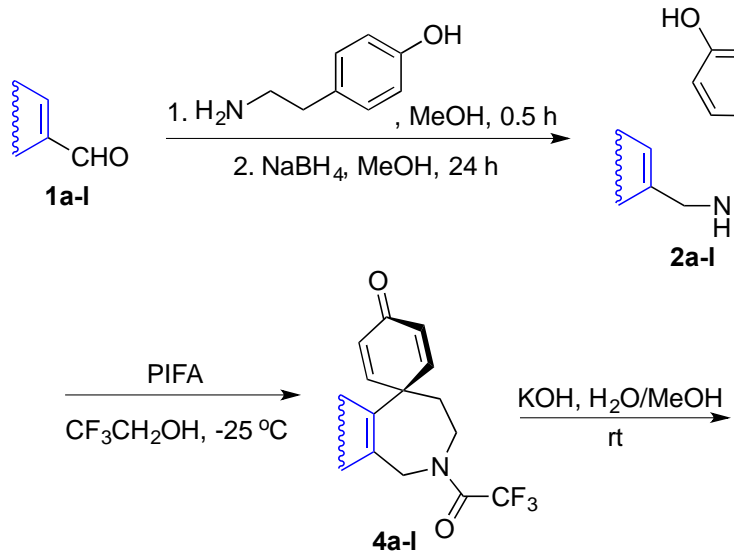
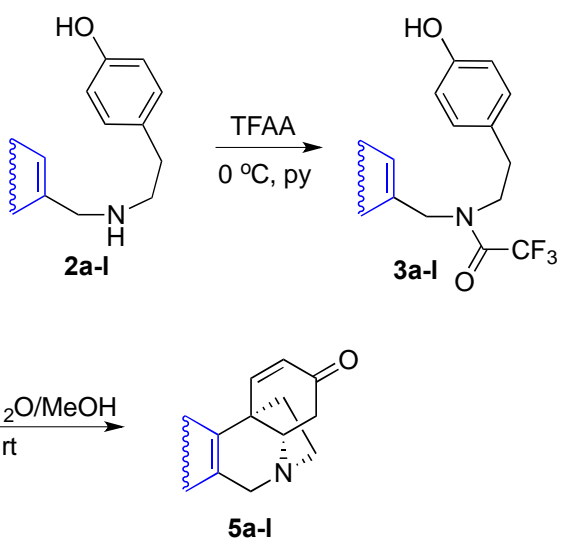

Scheme 2. General route toward synthetic analogues of the crinine-like alkaloids

Table 1. Compound structures and synthetic yields

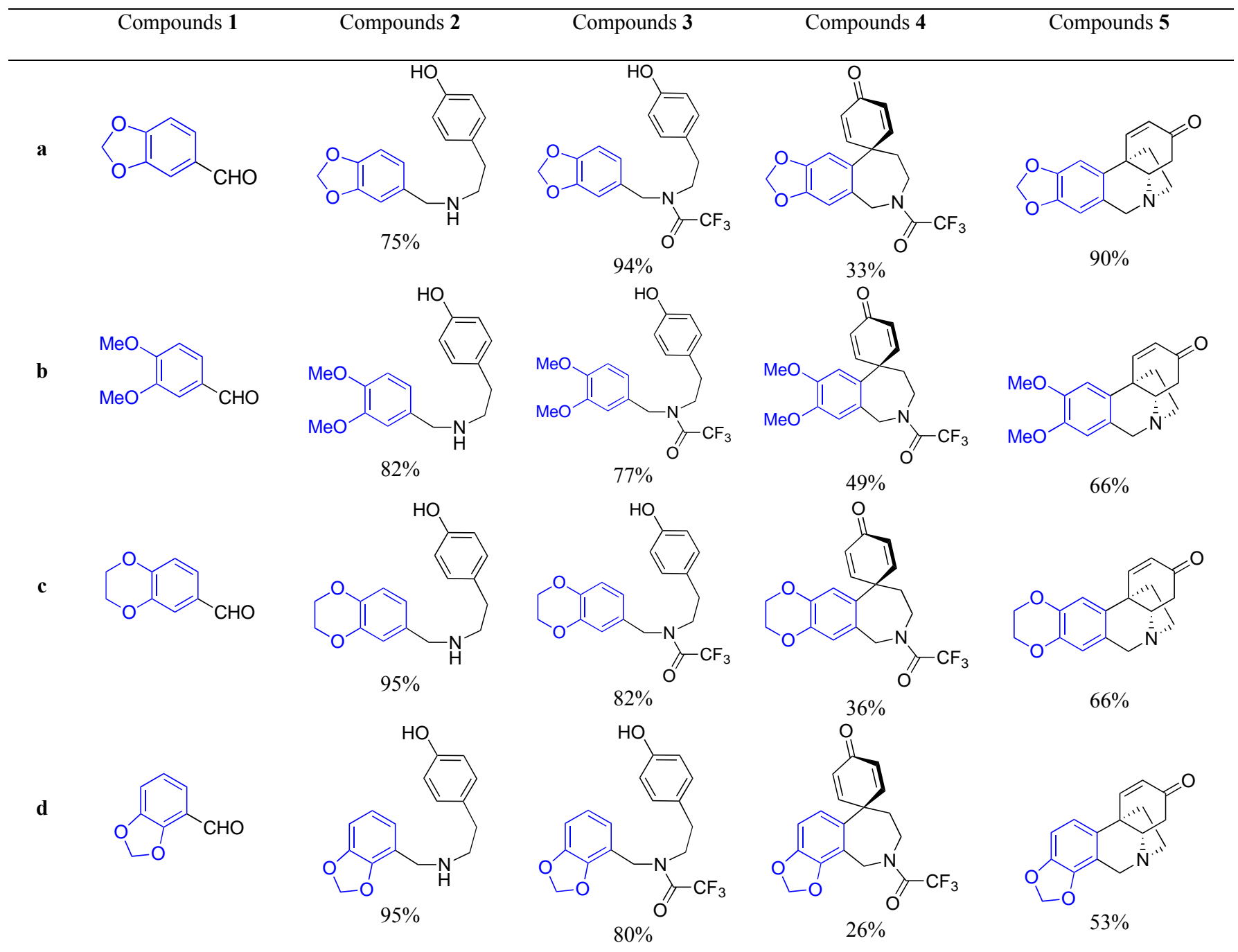


e<smiles>COc1ccc(C=O)cc1OCc1ccccc1</smiles>

f<smiles>COc1cc(C=O)ccc1OCc1ccccc1</smiles>

g<smiles>O=Cc1ccc(OBr)c(OCc2ccccc2)c1</smiles>

h<smiles>O=Cc1cccc(OCc2ccccc2)c1</smiles>

i

j<smiles>O=Cc1ccsc1</smiles><smiles>COc1ccc(CNCCc2ccc(O)cc2)cc1OCc1ccccc1</smiles>

$89 \%$<smiles>COc1cc(CNCCc2ccc(O)cc2)ccc1OCc1ccccc1</smiles><smiles>[Te][TeH]</smiles>

$\mathrm{HO}$<smiles>CC(C)(C)c1cccc(CNCCc2ccc(O)cc2)c1</smiles>
used as crude<smiles>Oc1ccc(CCNCc2cccc(OCc3ccccc3)c2)cc1</smiles>
$95 \%$<smiles>COc1ccc(CN(CCc2ccc(O)cc2)C(=O)C(F)(F)F)cc1OCc1ccccc1</smiles>

$95 \%$<smiles>COc1cc(CN(CCc2ccc(O)cc2)C(=O)C(F)(F)F)ccc1OCc1ccccc1</smiles>

$81 \%$<smiles>O=C(N(CCc1ccc(O)cc1)Cc1ccc(OCc2ccccc2)c(OCc2ccccc2)c1)C(F)(F)F</smiles>
$64 \%$<smiles>O=C(N(CCc1ccc(O)cc1)Cc1cccc(OCc2ccccc2)c1)C(F)(F)F</smiles>

$88 \%$<smiles>Oc1ccc(CCNCc2ccsc2)cc1</smiles>

$60 \%$

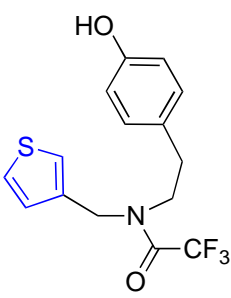

$77 \%$<smiles>O=C1C=CC2(C=C1)CCN(C(=O)C(F)(F)F)Cc1cc(OCc3ccccc3)ccc12</smiles><smiles>O=C1C=CC2(CC1)CCN(C(=O)C(F)(F)C(F)(F)F)Cc1cccc(Br)c12</smiles><smiles>COc1cc2c(cc1OCc1ccccc1)CN(C(=O)C(F)(F)F)CCC21C=CC(=O)C=C1</smiles><smiles>COc1cc2c(cc1OCc1ccccc1)C1(C=CC(=O)C=C1)CCN(C(=O)C(F)(F)F)C2</smiles>

$41 \%$<smiles>O=C1C=CC2(C=C1)CCN(C(=O)C(F)(F)F)Cc1cc(OCc3ccccc3)c(OCc3ccccc3)cc12</smiles><smiles>COc1cc2c(cc1OCc1ccccc1)C13C=CC(=O)CC1(CN2)C3</smiles>

$30 \%$<smiles></smiles>

$44 \%$<smiles>O=C1C=CC23C[C@H]1N(Cc1cc(OCc4ccccc4)ccc12)C3</smiles>

$40 \%$

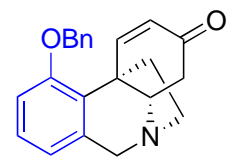

$45 \%$

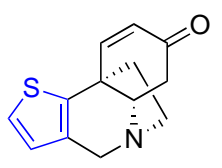

$40 \%($ from $\mathbf{4} \mathbf{k}+\mathbf{4} \mathbf{j})$

isolated as inseparable mixture with $\mathbf{4 k}$

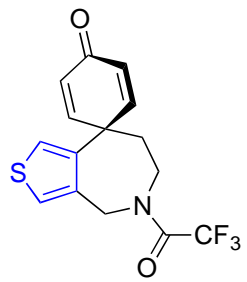

isolated as inseparable mixture with $\mathbf{4 j}$ 
I

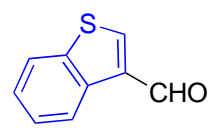

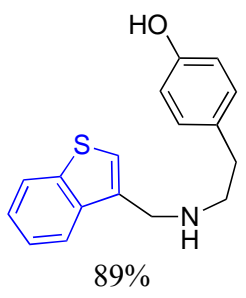

$89 \%$

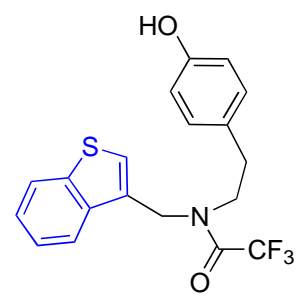

$95 \%$

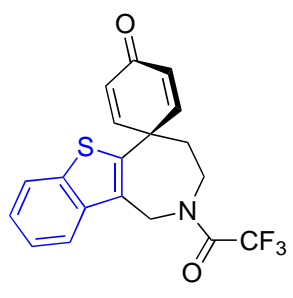

$41 \%$

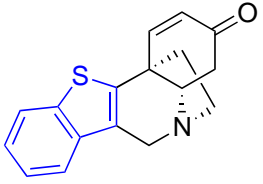

$74 \%$

To obtain additional 5,10b-ethanophenanthridines inaccessible by the direct oxidative coupling approach, crinine alkaloid noroxomaritidine $(\mathbf{5 m})$, containing a free phenolic hydroxyl, was prepared utilizing a published procedure involving debenzylation of spirodienone $\mathbf{4 e}$ to phenol $\mathbf{4 m}$ followed by intramolecular cyclization upon treatment with potassium hydroxide (Scheme 3). This synthetically prepared alkaloid was derivatized at the phenolic hydroxyl to obtain esters $\mathbf{5 n}, \mathbf{5 0}, \mathbf{5 p}$ and converted to oxime 5q.<smiles>COc1cc2c(cc1O)CN(C(=O)C(F)(F)F)CCC21C=CC(=O)C=C1</smiles>

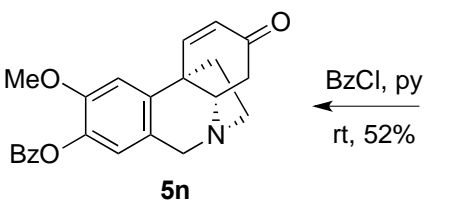<smiles>COc1cc2c(cc1O)C[NH+]1CC[C@H](C)[C@]23C=CC(=O)C[C@H]13</smiles>

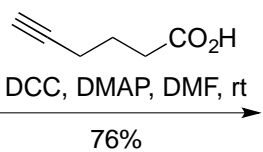

$5 \mathrm{~m}$ $\left(\mathrm{NH}_{3} \mathrm{OH}\right)_{2} \mathrm{SO}_{4}$ $\mathrm{py} / \mathrm{EtOH}, \mathrm{rt}, 70 \%$<smiles>COc1cc2c(cc1OC(C)=O)C13C=CC(=O)CC1(C)[C@H](C2)NC3</smiles>

$5 p$<smiles>COc1cc2c(cc1O)CN1CCC3(C=CC(=NO)CC3)[C@@]21C</smiles>

$5 q$<smiles>C#CCCCC(=O)Oc1cc2c(cc1OC)C1=CC=CC3=C(C[NH2+]CC3)C12</smiles>

Scheme 3. Synthesis and derivatization of noroxomaritidine (5m)

\subsection{Pharmacology}

\subsubsection{Structure-Activity Relationship}


Because spirodienones $\mathbf{4}$ have not to our knowledge been evaluated for anticancer activities before, these compounds, together with the desired 5,10b-ethanophenanthridines 5, were subjected to in vitro growth inhibition MTT assay ${ }^{55}$ against two cell lines, human HeLa cervical and MCF-7 breast adenocarcinomas (Table 2). Depending on the type of the aromatic ring A, the antiproliferative $\mathrm{GI}_{50}$ values for 5,10b-ethanophenanthridines 5a-5p, containing the C3-carbonyl moiety, ranged from single digit to $>100$ micromolar. High potency appeared to be associated with compounds containing large hydrophobic ether substituents in the ring A portion of the molecule (e.g., 5e-5i and 5l). The most noteworthy are compounds $\mathbf{5 g}$ and $\mathbf{5 l}$, incorporating two benzyl substituents and a novel benzothiophene-based bicyclic ring system, respectively, possessing single digit micromolar GI50 values. In contrast, the compounds, whose ring A is substituted with large ester moieties (5n and 5o) were only weakly active, demonstrating the importance of maintaining the electron-rich character of ring $\mathrm{A}$. Conversion of the $\mathrm{C} 3$-carbonyl to the oxime functionality also resulted in a loss of activity (see 5q). Most unexpectedly, spirodienones $\mathbf{4 a - 4 m}$ produced a range of activities that paralleled that of the 5,10b-ethanophenanthridines $\mathbf{5 a - 5 m}$, to which they are converted upon hydrolytic removal of the trifluoracetamide protection. For example, this is clearly pronounced in the potent $4 \mathbf{l} / \mathbf{5 l}$, inactive $\mathbf{4 m} / \mathbf{5 m}$ or moderately active $\mathbf{4 a} / \mathbf{5 a}$ pairs. This raises the question of whether compounds $\mathbf{4}$ undergo intracellular hydrolysis by non-specific amidases or even esterases ${ }^{56}$ followed by an intramolecular cyclization to release the active compounds $\mathbf{5}$. The hydrolytic lability of the trifluoroacetamide group has been observed to be even higher than that of a methyl $\operatorname{ester}^{57}$ and, although it appears there are no examples of this functionality in clinically approved drugs, ester-containing prodrugs that undergo hydrolysis to release the active drug are common. ${ }^{58}$

Table 2. Antiproliferative activities of spirodienones 4 and 5,10b-ethanophenanthridines 5 


\begin{tabular}{|c|c|c|c|c|c|c|c|c|}
\hline \multirow[t]{2}{*}{ compound } & \multicolumn{2}{|c|}{$\begin{array}{l}\text { cell viability } \\
\text { GI }_{50}, \mu \mathrm{M}\end{array}$} & \multirow[t]{2}{*}{ compound } & \multicolumn{2}{|c|}{$\begin{array}{l}\text { cell viability } \\
\quad \mathrm{GI}_{50}, \mu \mathrm{M}\end{array}$} & \multirow[t]{2}{*}{ compound } & \multicolumn{2}{|c|}{$\begin{array}{l}\text { cell viability } \\
\text { GI }_{50}, \mu \mathrm{M}\end{array}$} \\
\hline & $\mathrm{HeLa}$ & MCF-7 & & HeLa & MCF-7 & & HeLa & MCF-7 \\
\hline $4 a$ & $24 \pm 2$ & $30 \pm 2$ & $4 f$ & $34 \pm 4$ & $34 \pm 2$ & $4 k$ & NI & NI \\
\hline $5 \mathbf{a}$ & $25 \pm 3$ & $24 \pm 1$ & $5 f$ & $17 \pm 2$ & $17 \pm 0$ & $5 k$ & $25 \pm 5$ & $44 \pm 2$ \\
\hline $4 b$ & $83 \pm 5$ & $>100$ & $4 \mathrm{~g}$ & $17 \pm 1$ & $25 \pm 2$ & 41 & $10 \pm 0$ & $7 \pm 1$ \\
\hline $5 b$ & $64 \pm 3$ & $>100$ & $5 \mathrm{~g}$ & $3 \pm 1$ & $4 \pm 0$ & 51 & $8 \pm 1$ & $5 \pm 0$ \\
\hline $4 c$ & $21 \pm 1$ & $34 \pm 12$ & $4 \mathrm{~h}$ & $16 \pm 0$ & $40 \pm 1$ & $4 m$ & $>100$ & $>100$ \\
\hline $5 c$ & $13 \pm 2$ & $19 \pm 1$ & $5 \mathrm{~h}$ & $8 \pm 0$ & $14 \pm 1$ & $5 \mathrm{~m}$ & $>100$ & $>100$ \\
\hline $4 d$ & $>100$ & $>100$ & $4 i$ & $11 \pm 2$ & $14 \pm 2$ & $5 n$ & $35 \pm 1$ & $45 \pm 1$ \\
\hline $5 d$ & $61 \pm 5$ & $73 \pm 3$ & $5 i$ & $7 \pm 1$ & $11 \pm 1$ & 50 & $43 \pm 2$ & $53 \pm 1$ \\
\hline $4 e$ & $38 \pm 2$ & $48 \pm 3$ & $4 j$ & $\mathrm{NI}^{\mathrm{b}}$ & NI & $5 p$ & $>100$ & $>100$ \\
\hline $5 e$ & $12 \pm 1$ & $15 \pm 1$ & $5 j$ & $8 \pm 1$ & $12 \pm 0$ & $5 q$ & $>100$ & $>100$ \\
\hline
\end{tabular}

${ }^{a}$ Concentration required to reduce the viability of cells by $50 \%$ after a $48 \mathrm{~h}$ treatment with the indicated compounds relative to a DMSO control \pm SD from two independent experiments, each performed in 4 replicates, as determined by the MTT assay. ${ }^{\mathrm{b}} \mathrm{NI}=$ not isolated in pure form

\subsubsection{Activity against cells exhibiting intrinsic resistance to apoptosis, MDR phenotype, stem-like cell properties and other clinically relevant types of drug resistance}

Based on our previous studies with the alkaloid bulbispermine, ${ }^{48}$ found to retain activity against apoptosis-resistant glioblastoma cells, the synthesized compounds were evaluated for in vitro growth inhibition against a panel of additional cancer cell lines containing $\mathrm{U} 373,{ }^{59,60} \mathrm{U} 251,{ }^{61} \mathrm{U} 87,{ }^{61} \mathrm{~T}^{8} \mathrm{G}^{59}$ human GBM and A549 NSCLC, ${ }^{62}$ all exhibiting various degrees and mechanisms of apoptosis resistance, as well as an apoptosis-sensitive tumor model, Hs683 anaplastic oligodendroglioma, ${ }^{59}$ used as reference. The obtained GI50 values associated with spirodienone 4l, 5,10b-ethanophenanthridines $\mathbf{5 l}$ and $\mathbf{5 g}$ and bulbispermine control are shown in Table 3. The data reveal that these compounds retain the single-digit micromolar antiproliferatve $\mathrm{GI}_{50}$ values in this challenging cancer cell panel making 
them more potent than our previously studied lead, alkaloid bulbispermine, displaying double-digit micromolar potencies.

Table 3. Antiproliferative activities of spirodienone $\mathbf{4 l}$ and crinine analogues $\mathbf{5 g}$ and $\mathbf{5 l}$ against cancer cells displaying various types of drug resistance

GI $_{50}$ in vitro values $(\mu \mathrm{M})^{\mathrm{a}}$

\begin{tabular}{|c|c|c|c|c|c|c|c|c|c|c|c|c|}
\hline \multirow[b]{2}{*}{ compound } & \multicolumn{7}{|c|}{ glioma } & \multicolumn{3}{|c|}{ lung cancer } & \multicolumn{2}{|c|}{ uterine sarcoma } \\
\hline & Hs683 & U373 & U251 & U87 & T98G & $\begin{array}{c}\text { GBM } \\
090909\end{array}$ & $\begin{array}{c}\text { GBM } \\
031810\end{array}$ & A549 & H1993 & H2073 & MES-SA & $\begin{array}{l}\text { MES- } \\
\text { SA/Dx5 }\end{array}$ \\
\hline 41 & 5 & 7 & 4 & 6 & 15 & 7 & 8 & $--^{b}$ & 12 & 50 & 5 & 5 \\
\hline 51 & 3 & 2 & 1 & 2 & 7 & 5 & 1 & 9 & 3 & 11 & 5 & 7 \\
\hline $5 g$ & 6 & 7 & 5 & 5 & 7 & -- & -- & 4 & -- & -- & 2 & 7 \\
\hline $\begin{array}{l}\text { bulbisper } \\
\text { mine }\end{array}$ & 27 & 53 & 41 & 38 & 99 & -- & -- & -- & -- & -- & -- & -- \\
\hline TMZ & -- & -- & -- & -- & -- & 50 & $>1000$ & -- & -- & -- & -- & -- \\
\hline paclitaxel & -- & -- & -- & -- & -- & -- & -- & -- & 0.004 & 2.4 & 0.007 & 10 \\
\hline
\end{tabular}

${ }^{a}$ Average concentration required to reduce the viability of cells by $50 \%$ after a $48-96 \mathrm{~h}$ treatment with the indicated compounds in varied numbers of replicates, as determined by the MTT assay. ${ }^{\mathrm{b}}--=$ not tested

It is often observed that cells resistant to various pro-apoptotic stimuli contain a sensitive population that quickly responds to pro-apoptotic agents, but a significant portion of the cells in the culture resists the effects of the pro-apoptotic agents even at concentrations 100 - or 1000-fold of their GI50 values. ${ }^{60}$ 
Figures 2A-C show the absence of such resistant populations in five GBM cell lines treated with spirodienone $\mathbf{4 l}$ and 5,10b-ethanophenanthridines $\mathbf{5 g}$ and 5l. Indeed, as can be seen on the example of apoptosis-resistant A549 NSCLC cells (Figure 2D), crinine analogues $\mathbf{5 g}$ and $\mathbf{5 l}$ are equally effective against most of the cells in the A549 NSCLC cultures and, with increasing concentration, rapidly reach antiproliferative levels of a non-discriminate cytotoxic agent phenyl arsine oxide (PAO). In contrast, common proapoptotic agents paclitaxel and podophyllotoxin have no effect on proliferation of ca. $50 \%$ of cells in these cultures at concentrations up to $100 \mu \mathrm{M}$.
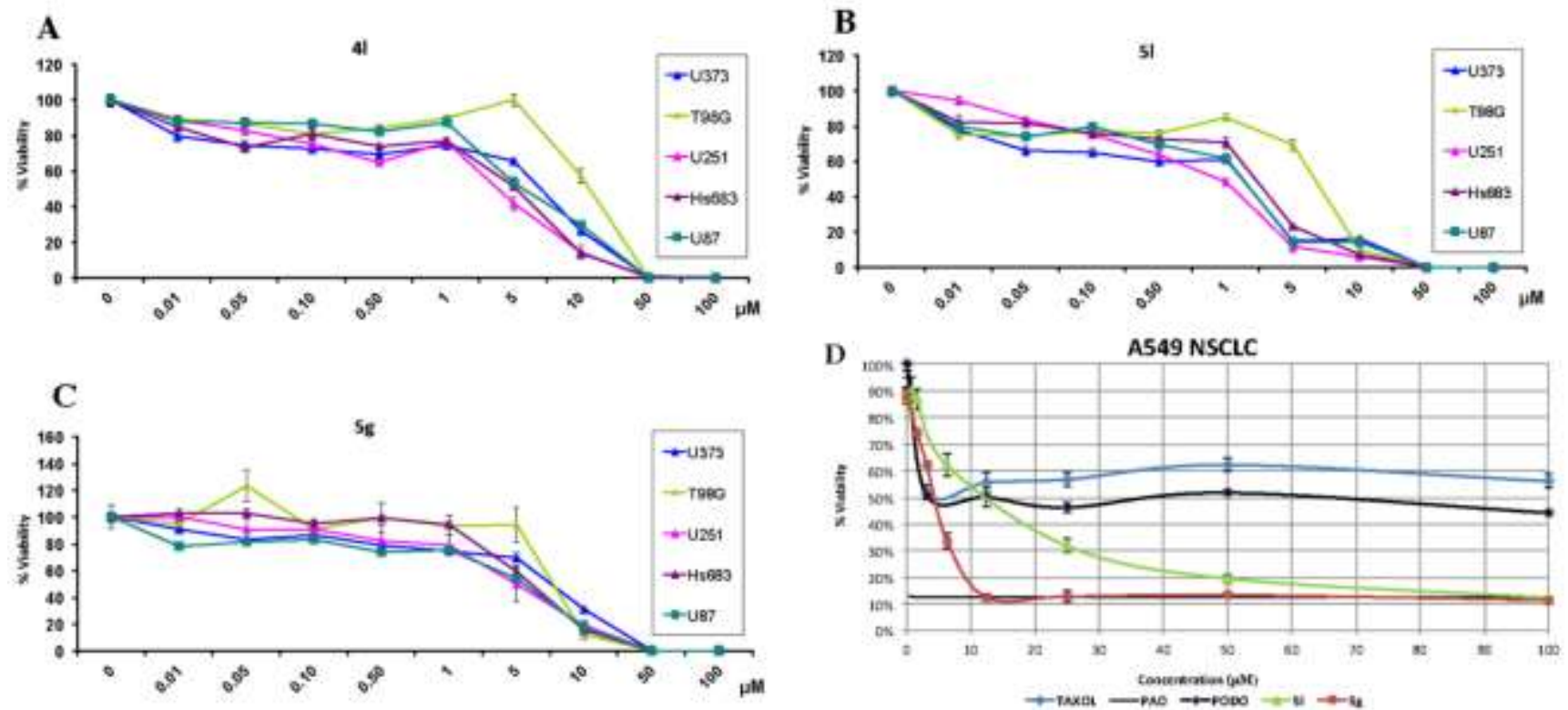

Figure 2. Activity of spirodienone $\mathbf{4 l}$ and crinine analogues $\mathbf{5 g}$ and $\mathbf{5 l}$ against cell populations resistant to proapoptotic agents determined with the MTT assay. A-C: growth curves of five GBM cell cultures treated with $\mathbf{4 l}, \mathbf{5} \mathbf{l}$ and $\mathbf{5 g}$, respectively (one experiment performed in six replicates). D: growth curves of A549 NSCLC cell cultures treated with 5l, 5g, paclitaxel, phenyl arsine oxide (PAO) and podophyllotoxin (PODO, two independent experiments, each performed in 4 replicates). 
It has been shown that glioma cells grown in neurosphere conditions exhibit stem-like properties through the ability of self-renewal and differentiation into multiple neural lineages. Furthermore, such cells recapitulate human gliomas on both histological and genetic levels more faithfully than serum cultured glioma cell lines when injected into the brains of mice ${ }^{63-66}$ and are generally resistant to radiation and chemotherapy. ${ }^{67-70}$ It is thus noteworthy that spirodienone $\mathbf{4 l}$ and $5,10 \mathrm{~b}$ ethanophenanthridine $\mathbf{5 l}$ retained similar levels of activity in neurosphere cultures 090909 and 031810 (Table 3). The former line, 090909, was derived from a patient who initially responded to TMZ, whereas the latter was derived from the same patient after progressing on temozolomide due to high $\mathrm{O}^{6}$-methylguanine-DNA-methyltransferase (MGMT) expression. MGMT is a protein capable of repairing mutagenic lesions produced by TMZ, therefore elevated MGMT expression confers resistance to TMZ even at concentrations as high as 1000 micromolar (Table 2). Importantly, methylation arrays show that almost $50 \%$ of patients with GBM have tumors that are unmethylated at the MGMT promoter site, leading to temozolomide resistance and poor outcome. ${ }^{71}$ To date, no alternative treatment exists for this group of patients. ${ }^{71}$

Further, spirodienone $\mathbf{4 1}$ and 5,10b-ethanophenanthridine $\mathbf{5 1}$ were evaluated against patient-derived NSCLC cell line H1993 and its drug-resistant variant H2073. The former was obtained from a lymph node metastasis isolated prior to chemotherapy, whereas the latter was derived from a regrown tumor at the primary site after the patient relapsed several months later. ${ }^{72}$ Drug resistance of the H2073 cells is exemplified by the loss of responsiveness toward paclitaxel by several orders of magnitude relative to their H1993 counterparts (Table 3). Although the potencies of $\mathbf{4} \mathbf{l}$ and $\mathbf{5 l}$ also decrease against the H2073 cells, the drop is significantly less pronounced than that observed with paclitaxel (Table 3). Furthermore, it was found that both $\mathbf{4 l}$ and $\mathbf{5 l}$ synergize with paclitaxel in their antiproliferative action against the H1993 cell line (Figure 3), indicating a potential use of these compounds as adjuvants to conventional chemotherapy for drug-resistant cancers. 

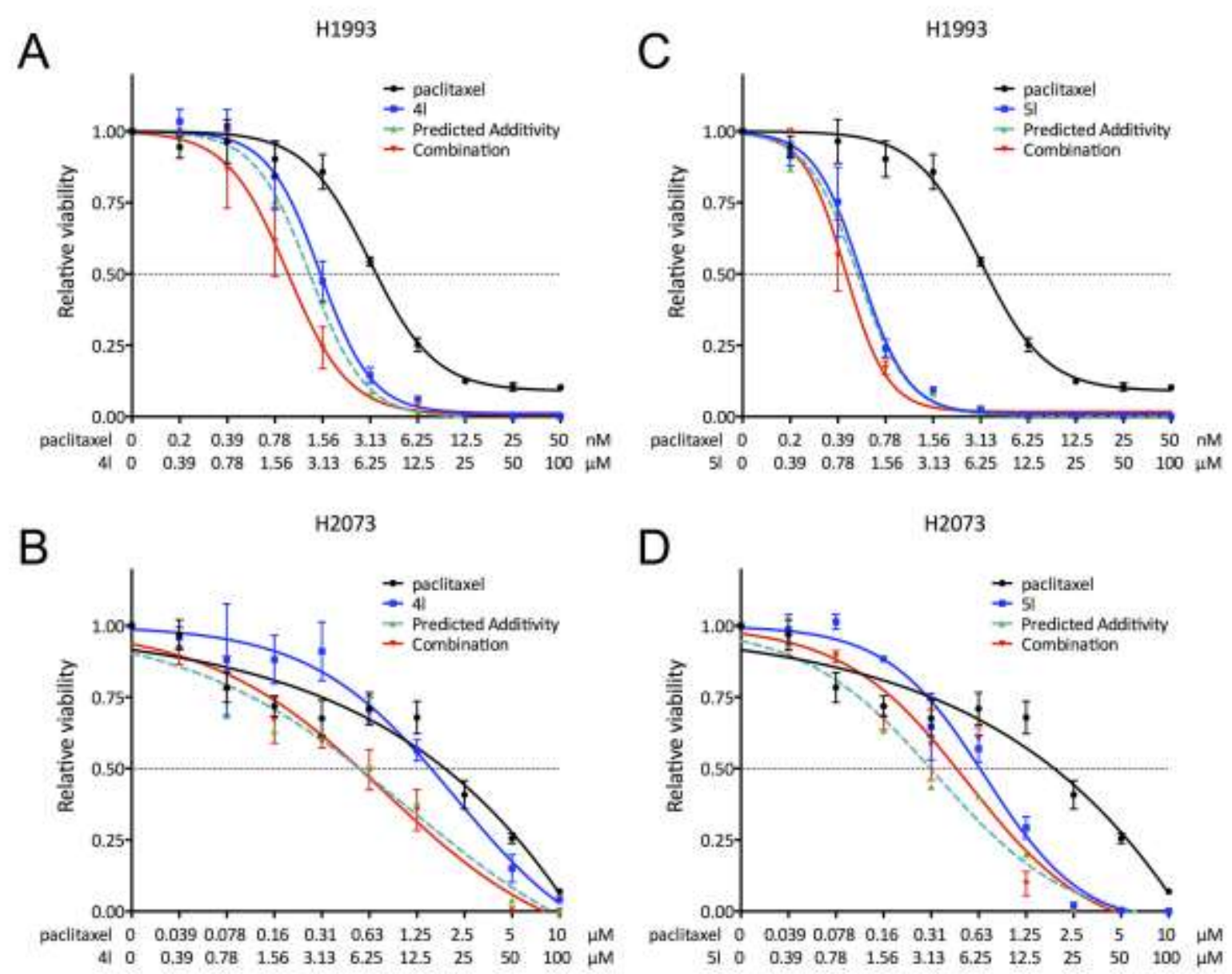

Figure 3. Combination treatment of paclitaxel with $4 \mathbf{l}(\mathrm{A}$ and $\mathrm{B})$ and $\mathbf{5 l}(\mathrm{C}$ and $\mathrm{D})$ illustrating synergism against H1993 cells. H1993 is an NSCLC cell line and H2073 is its drug-resistant counterpart.

Finally, to assess whether our compounds are substrates for the MDR cancer efflux systems, $\mathbf{4 I}$, $\mathbf{5 I}$ and 5g were evaluated against the MDR uterine sarcoma cell line MES-SA/Dx5. This cell line was established from the parent uterine sarcoma MES-SA, grown in the presence of increasing concentrations of doxorubicin and is known to be resistant to a number of P-gp substrates. ${ }^{73}$ Both paclitaxel (Table 3) and vinblastine (not shown) displayed more than a thousand fold drop in potency when tested for antiproliferative activity against the MDR cell line as compared with the parent one. In 
contrast, there was only a small variation in the activities of our compounds, indicating their potential to overcome clinical multi-drug resistance (Table 3).

\subsubsection{Inhibition of translation}

Because the earlier work revealed the translation inhibitory properties associated with the crinine-type alkaloids ${ }^{45}$ it was important to test benzothiophene $\mathbf{5 l}$ in quantitative assays ${ }^{74}$ assessing this biological activity (Figure 4). As such, we performed in vitro translation assays in both Krebs-2 and rabbit reticulocyte lysates programmed with the bicistronic FF/HCV/Ren mRNA (Figure 4A). Compared to previously characterized inhibitors of translation initiation (Hipp; hippuristanol) and elongation (Aniso; anisomycin, Lyco; lycorine, and Haeman; haemanthamine), 5l (CR-10) showed modest activity at inhibiting translation from both the FF (firefly) and Ren (renilla) cistrons $(\sim 25 \%$ inhibition). We then assessed the potency of $\mathbf{5 1}$ in vivo by monitoring polysome profiles (Figure 4B). The polysome distribution revealed that cells treated with lycorine and haemanthamine retained intact polysomes as previously reported for amaryllidaceae alkaloids which "freeze" polysomes and do not allow run-off or disaggregation of polysomes. ${ }^{45}$ In contrast, $5 \mathbf{l}$ (CR-10) led to a complete disaggregation of polysomes (Figure 4B). We then probed extracts from HeLa cells exposed to lycorine, haemanthamine, or $\mathbf{5 l}$ and found that $\mathbf{5 l}$ (CR-10) caused profound eIF2 $\alpha$ phosphorylation, compared to vehicle, lycorine or haemanthamine (Figure 4C). These results indicate that $\mathbf{5 l}$ is not an effective inhibitor of translation in vitro, but blocks translation in vivo by a mechanism that appears distinct from lycorine and haemanthamine involving eIF2 $\alpha$ phosphorylation. 
A

FF/HCV/Ren

\begin{tabular}{cc} 
SP6 & HCV \\
Promoter FF Luc & IRES Ren Luc \\
\hline
\end{tabular}
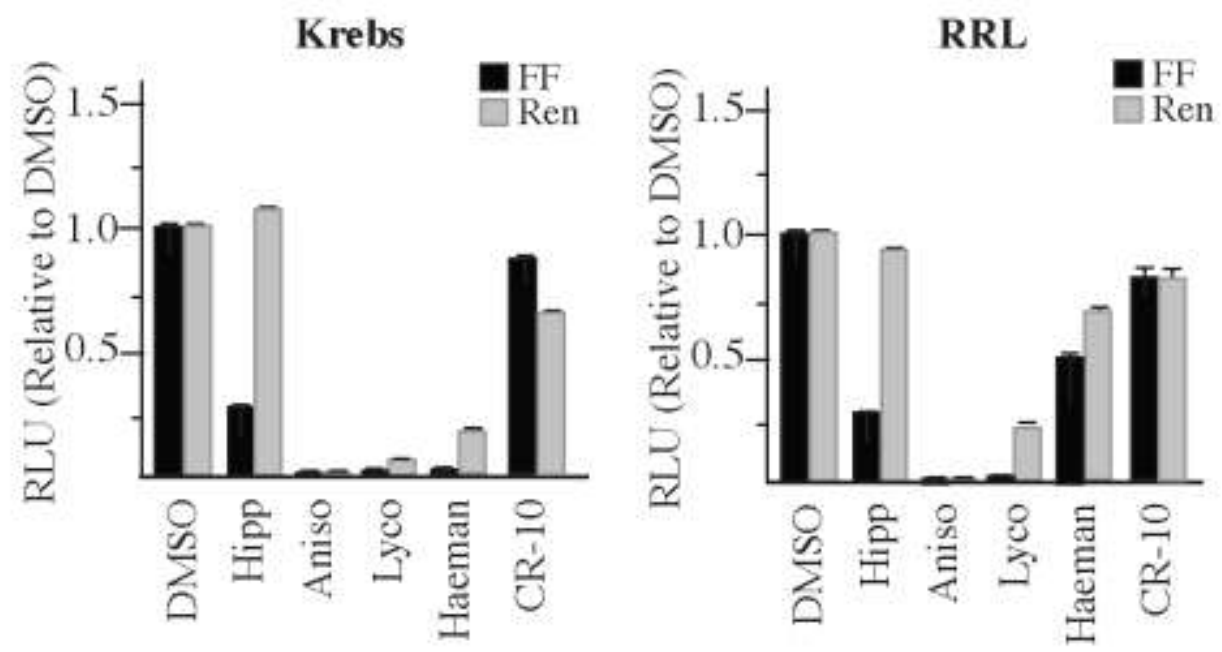

B
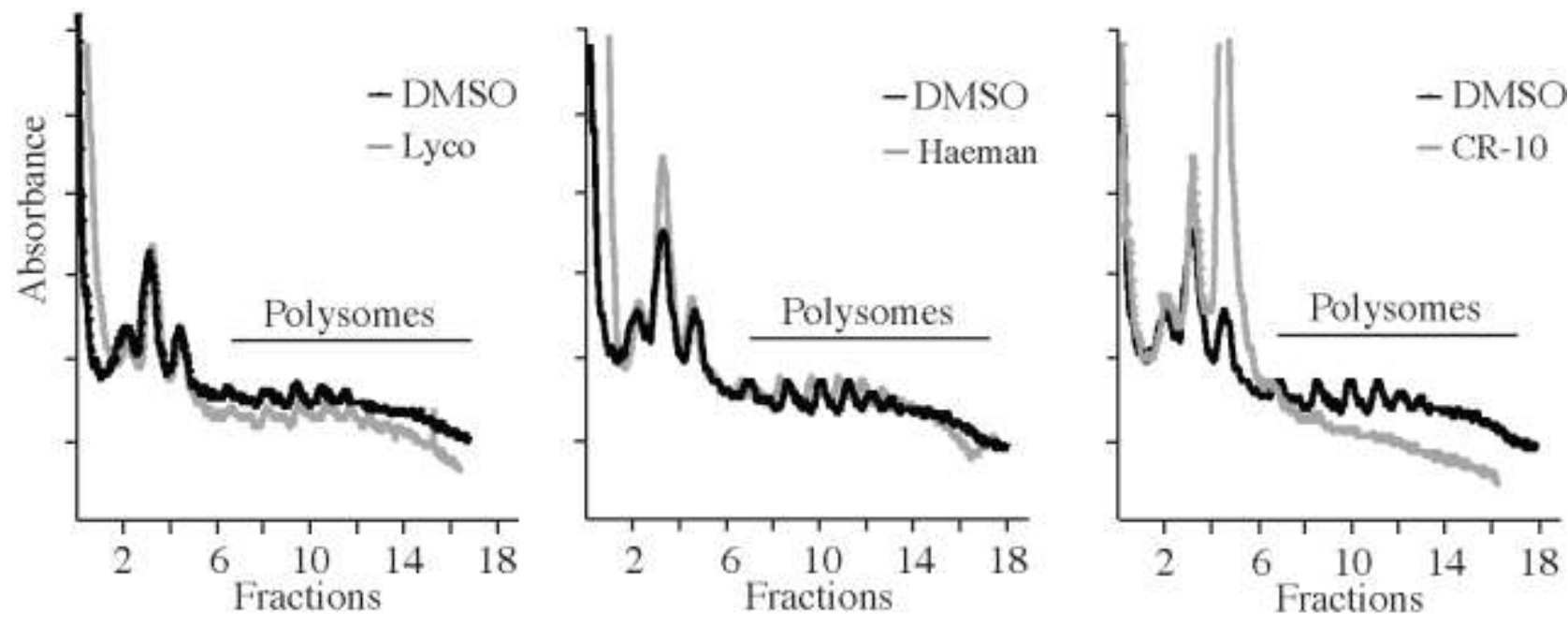

C

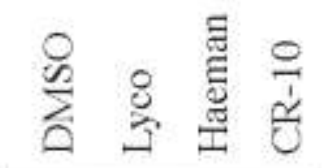

$$
\begin{aligned}
& \text { p-eIF } 2 \alpha \\
& \text { pan eIF } 2 \alpha \\
& \text { eEF2 } \\
& \begin{array}{llll}
1 & 2 & 3 & 4
\end{array}
\end{aligned}
$$


Figure 4. 5l (CR-10) Blocks Translation Initiation. A. Effect of CR-10 on cap- and HCV- mediated in vitro translation in Krebs-2 extract and rabbit reticulocyte lysate (RRL). Upper panel: Schematic diagram of bicistronic mRNA used for in vitro translation assays. Lower panels: Krebs-2 translation extracts (left) or RRL (right) were programmed with FF/HCV/Ren mRNA and incubated with vehicle $(0.5 \% \mathrm{DMSO})$ or the indicated compounds. The relative luciferase activity compared to the DMSO control from 2 independent translation reactions along with the error of the mean is presented. Reactions contained $1 \mu \mathrm{M}$ hippuristanol (Hipp), $10 \mu \mathrm{M}$ anisomycin (aniso), $50 \mu \mathrm{M}$ lycorine (Lyco), 50 $\mu \mathrm{M}$ haemanthamine (Haeman), or $50 \mu \mathrm{M} 5 \mathbf{l}$ (CR-10). B. Polysome profiling analyses of HeLa S3 cells exposed to $50 \mu \mathrm{M}$ compound for $1 \mathrm{~h}$. Polysomes for Lyco and $\mathbf{5 l}(\mathrm{CR}-10)$ are from the same experiment so the DMSO control profile is the same in the two plots shown. C. $\mathbf{5 l}(\mathrm{CR}-10)$ induces phosphorylation of eIF2 $\square$. HeLa S3 cells were treated with $50 \mu \mathrm{M}$ compound for $1 \mathrm{~h}$. Extracts were prepared, fractioned by SDS-PAGE, and transferred to a Immobilon-P PVDF membrane. Western blots were performed with the antibodies directed to the indicated proteins.

\section{Conclusion}

Drug resistance is one of the main causes for the failure of cancer chemotherapy. It can be intrinsic, involving apoptosis-resistant cancers such as glioma, melanoma or NSCLC, among others, or acquired, in which tumors innately respond to chemotherapy but eventually become refractory to a broad spectrum of structurally and mechanistically diverse antitumor agents. The results presented herein demonstrate the potential of a synthetic collection of compounds inspired by the crinine group of the Amaryllidaceae alkaloids for the treatment of drug-resistant cancers, regardless of whether the latter harbor intrinsic or acquired resistance mechanisms. The structural scaffold associated with the benzothiophene ring system $\mathbf{5 l}$ represents a new chemotype, whose further investigation is warranted by the described findings and should be facilitated by the straightforward biomimetic synthetic 
methodology utilized in this study. The spirodienone ring system, such as in $\mathbf{4 l}$, also represents an interesting structural type, which may serve as a prodrug of 51, undergoing enzymatic removal of the trifluoroacetamide group with the subsequent intramolecular cyclization to produce $\mathbf{5 l}$ in the cell. Although direct proof of this hypothesis requires further studies, the similarity of the biological effects between structurally different $\mathbf{4} \mathbf{l}$ and $\mathbf{5 l}$ certainly strongly supports this argument. In addition to these experiments, the ongoing work includes optimization of potency, further elucidation of mechanisms responsible for cytostatic/cytotoxic effects in this series of compounds as well as studies involving animal models of drug-resistant human cancer.

\section{Experimental Section}

\subsection{General Experimental.}

All reagents, solvents and catalysts were purchased from commercial sources (Acros Organics and Sigma-Aldrich) and used without purification. All reactions were performed in oven-dried flasks open to the atmosphere or under nitrogen or argon and monitored by thin layer chromatography (TLC) on TLC precoated $(250 \mu \mathrm{m})$ silica gel 60 F254 glass-backed plates (EMD Chemicals Inc.). Visualization was accomplished with UV light. Flash column chromatography was performed on silica gel (32-63

$\mu \mathrm{m}, 60 \AA$ pore size). ${ }^{1} \mathrm{H}$ and ${ }^{13} \mathrm{C}$ NMR spectra were recorded on a Bruker 400 spectrometer. Chemical shifts $(\delta)$ are reported in ppm relative to the TMS internal standard. Abbreviations are as follows: s (singlet), d (doublet), $\mathrm{t}$ (triplet), q (quartet), m (multiplet). The synthesized compounds are at least 95\% pure according to an HPLC/MS analysis.

\subsection{General procedure for the synthesis of compounds $2 \mathrm{a}-\mathrm{h}, 2 \mathrm{j}$ and $2 \mathrm{I}$}

To a flask containing $4.1 \mathrm{mmol}$ of a selected aromatic aldehyde in $10.2 \mathrm{~mL}$ of methanol at $0{ }^{\circ} \mathrm{C}$ were added $0.7452 \mathrm{~g}(5.4 \mathrm{mmol})$ of tyramine. The solution was allowed to stir for $45 \mathrm{~min}$ and $0.1808 \mathrm{~g}$ (4.8 
mmol) of sodium borohydride was added. The solution was allowed to stir for $4.5 \mathrm{~h}$, at which point $0.1679 \mathrm{~g}$ (4.4 mmol) of additional sodium borohydride was added. This mixture was stirred overnight and the formed precipitate was collected via vacuum filtration. No further purification was required at this stage. The NMR spectral data for known compounds $\left(\mathbf{2} \mathbf{a},{ }^{51} \mathbf{2} \mathbf{b},{ }^{50}\right.$ and $\left.\mathbf{2} \mathbf{e}^{50}\right)$ matched those in the literature. The characterization of all new compounds is given below.

\subsection{Compound 2c}

95\%, white solid, mp: $91-93{ }^{\circ} \mathrm{C}$ (decomp.); ${ }^{1} \mathrm{H}$ NMR $\left(\mathrm{CDCl}_{3}\right): \delta 6.96(\mathrm{~d}, J=8.0 \mathrm{~Hz}, 2 \mathrm{H}), 6.78-6.66(\mathrm{~m}$, 5H), $4.22(\mathrm{~m}, 4 \mathrm{H}), 3.69\left(\right.$ broad s, 2H), $2.84(\mathrm{t}, J=7.1 \mathrm{~Hz}, 2 \mathrm{H}), 2.72(\mathrm{t}, J=7.1 \mathrm{~Hz}, 2 \mathrm{H}) ;{ }^{13} \mathrm{C}$ NMR $\left(\mathrm{CDCl}_{3}\right): \delta 154.6(\mathrm{C}), 143.4(\mathrm{C}), 142.6(\mathrm{C}), 132.9(\mathrm{C}), 131.1(\mathrm{C}), 129.8(\mathrm{CHx} 2), 121.3(\mathrm{CH}), 117.2$ (CHx2), $117.1(\mathrm{CH}), 115.6(\mathrm{CH}), 64.3\left(\mathrm{CH}_{2} \mathrm{x} 2\right), 53.1\left(\mathrm{CH}_{2}\right), 50.2\left(\mathrm{CH}_{2}\right), 35.0\left(\mathrm{CH}_{2}\right)$; HRMS calc'd for $\mathrm{C}_{17} \mathrm{H}_{20} \mathrm{NO}_{3}(\mathrm{M}+\mathrm{H})^{+}:$286.1438, found 286.1441.

\subsection{Compound 2d}

95\%, white solid, mp: 89-91 ${ }^{\circ} \mathrm{C}$ (decomp.); ${ }^{1} \mathrm{H}$ NMR $\left(\mathrm{CDCl}_{3}\right): \delta 6.95$ (d, J=8.4 Hz, 2H), 6.89-6.65 (m, $5 \mathrm{H}), 5.81(\mathrm{~s}, 2 \mathrm{H}), 5.46($ broad s, $1 \mathrm{H}), 3.79(\mathrm{~s}, 2 \mathrm{H}), 2.85(\mathrm{t}, J=7.1 \mathrm{~Hz}, 2 \mathrm{H}), 2.74(\mathrm{t}, J=7.1 \mathrm{~Hz}, 2 \mathrm{H}) .{ }^{13} \mathrm{C}$ NMR (CDCl 3$): \delta 156.1(\mathrm{C}), 147.3(\mathrm{C}), 145.5(\mathrm{C}), 129.9$ (CHx2), $122.3(\mathrm{C}), 121.6(\mathrm{C}), 120.6(\mathrm{CH})$, 116.3(CHx2), $116.1(\mathrm{CH}), 107.8(\mathrm{CH}), 100.8\left(\mathrm{CH}_{2}\right), 50.0\left(\mathrm{CH}_{2}\right), 47.8\left(\mathrm{CH}_{2}\right), 34.7\left(\mathrm{CH}_{2}\right) . \mathrm{HRMS}$ calc'd for $\mathrm{C}_{16} \mathrm{H}_{18} \mathrm{NO}_{3}(\mathrm{M}+\mathrm{H})^{+}:$272.1281, found 272.1286 .

\subsection{Compound $2 f$}

97\%, white solid, mp: $65-67{ }^{\circ} \mathrm{C}$ (decomp.); ${ }^{1} \mathrm{H}$ NMR $\left(\mathrm{CDCl}_{3}\right): 7.40$ (d, J=7.2 Hz, 2H), 7.33 (t, $J=7.6$ $\mathrm{Hz}, 2 \mathrm{H}), 7.28(\mathrm{~d}, J=7.2 \mathrm{~Hz}, 1 \mathrm{H}), 7.01(\mathrm{~d}, J=8.4 \mathrm{~Hz}, 2 \mathrm{H}), 6.82(\mathrm{~d}, J=3.6 \mathrm{~Hz}, 1 \mathrm{H}), 6.78(\mathrm{~d}, J=8.2 \mathrm{~Hz}$, 1H), 6.70-6.68 (m, 3H), $5.11(\mathrm{~s}, 2 \mathrm{H}), 3.82(\mathrm{~s}, 3 \mathrm{H}), 3.70(\mathrm{~s}, 2 \mathrm{H}), 2.84(\mathrm{t}, J=6.5 \mathrm{~Hz}, 2 \mathrm{H}), 2.73(\mathrm{t}, J=7.2$ 
Hz, 2H). ${ }^{13} \mathrm{C}$ NMR $\left(\mathrm{CDCl}_{3}\right): \delta 154.4(\mathrm{C}), 149.8(\mathrm{C}), 147.2(\mathrm{C}), 137.4(\mathrm{C}), 133.2$ (CHx2), $131.5(\mathrm{C})$, $129.8(\mathrm{C}), 128.5(\mathrm{C}), 127.8(\mathrm{CH}), 127.3(\mathrm{CHx} 2), 120.3(\mathrm{CH}), 115.4(\mathrm{CHx} 2), 114.0(\mathrm{CH}), 112.0(\mathrm{CH})$, $71.2\left(\mathrm{CH}_{2}\right), 56.0\left(\mathrm{CH}_{3}\right), 53.6\left(\mathrm{CH}_{2}\right), 50.7\left(\mathrm{CH}_{2}\right), 35.2\left(\mathrm{CH}_{2}\right)$. HRMS calc'd for $\mathrm{C}_{23} \mathrm{H}_{26} \mathrm{NO}(\mathrm{M}+\mathrm{H})^{+}$: 364.1907, found 364.1912.

\subsection{Compound $2 \mathrm{~h}$}

95\%, white solid, mp: $83-85{ }^{\circ} \mathrm{C}$ (decomp.); ${ }^{1} \mathrm{H}$ NMR $\left(\mathrm{CDCl}_{3}\right): \delta$ 7.39-7.29 (m, 5H), $7.18(\mathrm{t}, J=7.8 \mathrm{~Hz}$, 1H), $6.97(\mathrm{~d}, J=8.4 \mathrm{~Hz}, 2 \mathrm{H}), 6.89(\mathrm{~s}, 1 \mathrm{H}), 6.83(\mathrm{~d}, J=8.4 \mathrm{~Hz}, 1 \mathrm{H}), 6.82(\mathrm{~d}, J=6.4 \mathrm{~Hz}, 1 \mathrm{H}), 6.65$ (d, $J=8.4 \mathrm{~Hz}, 2 \mathrm{H}), 4.94(\mathrm{~s}, 2 \mathrm{H}), 3.75(\mathrm{~s}, 2 \mathrm{H}), 2.85(\mathrm{t}, J=6.6 \mathrm{~Hz}, 2 \mathrm{H}), 2.73(\mathrm{t}, J=7.0 \mathrm{~Hz}, 2 \mathrm{H}) .{ }^{13} \mathrm{C} \mathrm{NMR}$ $\left(\mathrm{CDCl}_{3}\right): \delta 159.0(\mathrm{C}), 154.5(\mathrm{C}), 141.4(\mathrm{C}), 137.1$ (CHx2), 131.4 (CHx2), 129.8 (CHx2), $129.5(\mathrm{CH})$, $128.6(\mathrm{C}), 127.9(\mathrm{C}), 127.5(\mathrm{CH}), 120.8(\mathrm{C}), 115.5(\mathrm{CHx} 2), 114.5(\mathrm{CH}), 113.6(\mathrm{CH}), 69.9\left(\mathrm{CH}_{2}\right), 53.7$ $\left(\mathrm{CH}_{2}\right), 50.4\left(\mathrm{CH}_{2}\right), 35.1\left(\mathrm{CH}_{2}\right)$. HRMS calc'd for $\mathrm{C}_{22} \mathrm{H}_{24} \mathrm{NO}_{2}(\mathrm{M}+\mathrm{H})^{+}$: 334.1802 found 334.1807 .

\subsection{Compound 2j}

60\%, white solid, mp: $103-105{ }^{\circ} \mathrm{C}$ (decomp.); ${ }^{1} \mathrm{H}$ NMR (Acetone- $\left.d_{6}\right): \delta 7.32$ (dd, $J=3.0, J=2.5 \mathrm{~Hz}, 1 \mathrm{H}$ ), 7.17-7.16 (m, 1H), $7.02(\mathrm{dd}, J=1.0, J=2.5 \mathrm{~Hz}, 1 \mathrm{H}), 7.00(\mathrm{~d}, J=8.4 \mathrm{~Hz}, 2 \mathrm{H}), 6.70(\mathrm{~d}, J=8.4 \mathrm{~Hz}, 2 \mathrm{H})$, $3.75(\mathrm{~s}, 2 \mathrm{H}), 2.75(\mathrm{t}, J=6.9 \mathrm{~Hz}, 2 \mathrm{H}), 2.65(\mathrm{t}, J=6.9 \mathrm{~Hz}, 2 \mathrm{H}) .{ }^{13} \mathrm{C} \mathrm{NMR}\left(\mathrm{CDCl}_{3}\right): \delta 155.6(\mathrm{C}), 142.5(\mathrm{C})$, $131.2(\mathrm{CHx} 2), 129.5(\mathrm{C}), 127.7(\mathrm{CH}), 125.2(\mathrm{CH}), 120.9(\mathrm{CH}), 115.0(\mathrm{CHx} 2), 51.0\left(\mathrm{CH}_{2}\right), 48.4\left(\mathrm{CH}_{2}\right)$, 35.4 $\left(\mathrm{CH}_{2}\right)$. HRMS calc'd for $\mathrm{C}_{13} \mathrm{H}_{16} \mathrm{NOS}(\mathrm{M}+\mathrm{H})^{+}: 234.0947$, found 234.0952 .

\subsection{Compound 21}

89\%, white solid, mp: 99-101 ${ }^{\circ} \mathrm{C}$ (decomp.); ${ }^{1} \mathrm{H}$ NMR $\left(\mathrm{CDCl}_{3}\right)$ : $\delta$ 7.83-7.81 (m, 1H), 7.70-7.67 (m, 1H), 7.35-7.29 (m, 2H), 7.00 (d, $J=8.3 \mathrm{~Hz}, 2 \mathrm{H}), 6.67$ (d, $J=8.4 \mathrm{~Hz}, 2 \mathrm{H}), 4.03$ (s, 2H), 2.94 (t, $J=7.0 \mathrm{~Hz}$, 2H), $2.76(\mathrm{t}, J=7.0 \mathrm{~Hz}, 2 \mathrm{H}) .{ }^{13} \mathrm{C} \mathrm{NMR}\left(\mathrm{CDCl}_{3}\right): \delta 155.6(\mathrm{C}), 140.6(\mathrm{C}), 138.7$ (C), $136.1(\mathrm{C}), 131.2$ 
(CHx2), $129.6(\mathrm{C}), 124.2(\mathrm{CH}), 123.7(\mathrm{CH}), 122.6(\mathrm{CH}), 122.6(\mathrm{CH}), 122.3(\mathrm{CH}), 115.0(\mathrm{CHx}), 51.3$ $\left(\mathrm{CH}_{2}\right), 47.3\left(\mathrm{CH}_{2}\right), 35.4\left(\mathrm{CH}_{2}\right)$. HRMS calc'd for $\mathrm{C}_{17} \mathrm{H}_{18} \mathrm{NOS}(\mathrm{M}+\mathrm{H})^{+}:$: 284.1104, found 285.1108.

\subsection{General procedure for the synthesis of compounds $3 a-h, 3 j$ and 31}

To a dry flask containing $2.7 \mathrm{mmol}$ of a selected amine $\mathbf{2 a - 1}$ in $9.6 \mathrm{~mL}$ pyridine under argon were added $0.75 \mathrm{~mL}(5.2 \mathrm{mmol})$ of trifluoroacetic anhydride. The reaction was stirred at $0{ }^{\circ} \mathrm{C}$ for 1 day and quenched with $3 \mathrm{~mL}$ of methanol. The solution was concentrated in vacuo, dissolved in ethyl acetate, and washed twice with water and twice with brine. The solution was dried with sodium sulfate, filtered, concentrated in vacuo, and the desired product $\mathbf{3 a - h , ~} \mathbf{3} \mathbf{j}$ and $\mathbf{3 1}$ was purified by column chromatography (hexanes/ethyl acetate, 1.5:1). The NMR spectral data for known compounds $\left(\mathbf{3 a},{ }^{75}\right.$ $3 \mathbf{b}^{50}$ and $3 \mathbf{e}^{50}$ ) matched those in the literature. The characterization of all new compounds is given below.

\subsection{Compound 3c}

82\%, oil; ${ }^{1} \mathrm{H}$ NMR $\left(\mathrm{CDCl}_{3}\right): \delta 6.99(\mathrm{~d}, J=11.2 \mathrm{~Hz}, 2 \mathrm{H}), 6.95-6.58(\mathrm{~m}, 5 \mathrm{H}), 5.46(\mathrm{~s}, 1 \mathrm{H}), 4.51(\mathrm{~s}, 1 \mathrm{H})$, 4.26-4.22 (m, 5H), 3.45-3.41 (m, 2H), $2.78(\mathrm{t}, J=7.1 \mathrm{~Hz}, 1 \mathrm{H}), 2.72(\mathrm{t}, J=7.1 \mathrm{~Hz}, 1 \mathrm{H}) .{ }^{13} \mathrm{C}$ NMR (CDCl 3$): \delta 157.1$ (q, J=34.9 Hz, C), 154.8 (C), 154.6 (C), 143.9 (C), 143.8 (C), 143.6 (C), 143.5 (C), 130.1(C), 129.9 (C), 129.8 (C), 129.2 (C), 128.5 (CHx2), 127.8 (CHx2), $121.3(\mathrm{CH}), 120.6(\mathrm{CH})$, $117.7\left(\mathrm{CF}_{3}\right), 117.7(\mathrm{CHx}), 117.1(\mathrm{CHx}), 116.5(\mathrm{CH}), 115.8(\mathrm{CH}), 115.7(\mathrm{CH}), 115.6(\mathrm{CH}), 64.4$ $\left(\mathrm{CH}_{2} \times 2\right), 51.0\left(\mathrm{CH}_{2}\right), 50.9\left(\mathrm{CH}_{2}\right), 49.1\left(\mathrm{CH}_{2}\right), 48.4\left(\mathrm{CH}_{2}\right), 48.3\left(\mathrm{CH}_{2}\right), 48.3,34.3\left(\mathrm{CH}_{2}\right), 34.1\left(\mathrm{CH}_{2}\right)$, $31.9\left(\mathrm{CH}_{2}\right)$. HRMS calc'd for $\mathrm{C}_{19} \mathrm{H}_{18} \mathrm{~F}_{3} \mathrm{NNaO}_{4}(\mathrm{M}+\mathrm{Na})^{+}$: 404.1080 , found 404.1085 .

\subsection{Compound 3d}


80\%, oil; ${ }^{1} \mathrm{H} \mathrm{NMR}\left(\mathrm{CDCl}_{3}\right): \delta$ 6.99-6.96 (m, 2H), 6.81-6.72 (m, 5H), $5.94(\mathrm{~d}, J=7.0 \mathrm{~Hz}, 2 \mathrm{H}), 5.23(\mathrm{~s}$, 1H), $4.65(\mathrm{~s}, 1 \mathrm{H}), 4.43(\mathrm{~s}, 1 \mathrm{H}), 3.49(\mathrm{~m}, 2 \mathrm{H}), 2.83(\mathrm{t}, J=7.8 \mathrm{~Hz}, 1 \mathrm{H}), 2.74(\mathrm{t}, J=7.8 \mathrm{~Hz}, 1 \mathrm{H}) .{ }^{13} \mathrm{C}$ NMR $\left(\mathrm{CDCl}_{3}\right): \delta 157.3(\mathrm{q}, J=25.7 \mathrm{~Hz}, \mathrm{C}), 155.0(\mathrm{C}), 154.8(\mathrm{C}), 147.6(\mathrm{C}), 147.4(\mathrm{C}), 146.0(\mathrm{C}), 145.8(\mathrm{C})$, $129.9(\mathrm{C}), \quad 129.8\left(\mathrm{CH}_{2}\right), 129.7\left(\mathrm{CH}_{2}\right), 129.0(\mathrm{C}), 122.3(\mathrm{CH}), 122.2(\mathrm{CH}), 121.0(\mathrm{C}), 118.1(\mathrm{CH})$, $118.0(\mathrm{CH}), 116.7(\mathrm{CH}), 116.1\left(\mathrm{CF}_{3}\right), 115.8\left(\mathrm{CF}_{3}\right), 115.7\left(\mathrm{CF}_{3}\right), 115.6\left(\mathrm{CF}_{3}\right), 115.3\left(\mathrm{CH}_{2}\right), 115.1$ $\left(\mathrm{CH}_{2}\right), 108.7(\mathrm{CH}), 108.6(\mathrm{CH}), 101.2\left(\mathrm{CH}_{2}\right), 101.1\left(\mathrm{CH}_{2}\right), 48.9\left(\mathrm{CH}_{2}\right),, 48.7\left(\mathrm{CH}_{2}\right), 46.0\left(\mathrm{CH}_{2}\right), 45.9$ $\left(\mathrm{CH}_{2}\right), 44.2\left(\mathrm{CH}_{2}\right), 34.2\left(\mathrm{CH}_{2}\right), 31.9\left(\mathrm{CH}_{2}\right)$. HRMS calc'd for $\mathrm{C}_{18} \mathrm{H}_{16} \mathrm{~F}_{3} \mathrm{NNaO}_{4}(\mathrm{M}+\mathrm{Na})^{+}$: 390.0924 , found, 390.0927.

\subsection{Compound 3f}

81\%, oil; ${ }^{1} \mathrm{H}$ NMR $\left(\mathrm{CDCl}_{3}\right): \delta 7.43$ (d, $\left.J=7.8 \mathrm{~Hz}, 2 \mathrm{H}\right), 7.38-7.34$ (m, 2H), 7.32-7.28 (m, 1H), 6.98-6.95 $(\mathrm{m}, 2 \mathrm{H}), 6.85(\mathrm{dd}, J=6.6, \mathrm{~J}=4.0 \mathrm{~Hz}, 1 \mathrm{H}), 6.79-6.70(\mathrm{~m}, 3 \mathrm{H}), 6.65-6.61(\mathrm{~m}, 1 \mathrm{H}), 5.15(\mathrm{~d}, J=3.8 \mathrm{~Hz}, 2 \mathrm{H})$, $4.58(\mathrm{~s}, 1 \mathrm{H}), 4.33(\mathrm{~s}, 1 \mathrm{H}), 3.85(\mathrm{~d}, J=1.6 \mathrm{~Hz}, 3 \mathrm{H}), 3.49-3.43(\mathrm{~m}, 2 \mathrm{H}), 2.80(\mathrm{t}, J=7.4 \mathrm{~Hz}, 1 \mathrm{H}), 2.73(\mathrm{t}$, $J=7.1 \mathrm{~Hz}, 2 \mathrm{H}),{ }^{13} \mathrm{C} \mathrm{NMR}\left(\mathrm{CDCl}_{3}\right): \delta 157.3$ (q, $\left.J=86.7 \mathrm{~Hz}, \mathrm{C}\right) 155.1$ (C), 154.9 (C), 150.1 (C), 148.2 (C), 148.1 (C), 136.9 (C), 136.8 (C), 129.9 (CHx2), 129.7 (CHx2), 128.9 (C), 1, 128.6 (CHx2), 128.4 (CHx2), $128.0(\mathrm{CH}),, 127.5(\mathrm{CHx} 2), 127.4(\mathrm{CHx} 2), 120.8(\mathrm{CH}), 120.2\left(\mathrm{CF}_{3}\right), 115.8(\mathrm{CHx} 2), 114.1$ $(\mathrm{CH}), 114.0(\mathrm{CH}), 111.9(\mathrm{CH}), 111.1(\mathrm{CH}), 71.1\left(\mathrm{CH}_{2}\right), 56.1\left(\mathrm{CH}_{3}\right), 56.0\left(\mathrm{CH}_{3}\right)$, , $49.6\left(\mathrm{CH}_{2}\right), 48.4$ $\left(\mathrm{CH}_{2}\right), 34.3\left(\mathrm{CH}_{2}\right), 32.0\left(\mathrm{CH}_{2}\right)$. HRMS calc'd for $\mathrm{C}_{25} \mathrm{H}_{24} \mathrm{~F}_{3} \mathrm{NNaO}_{4}(\mathrm{M}+\mathrm{Na})^{+}:$482.1550, found 482.1555 .

\subsection{Compound $3 g$}

64\%, white solid, mp: $45-47{ }^{\circ} \mathrm{C} ;{ }^{1} \mathrm{H}$ NMR $\left(\mathrm{CDCl}_{3}\right): \delta 7.42-7.26(\mathrm{~m}, 10 \mathrm{H}), 7.03(\mathrm{~d}, J=6.6 \mathrm{~Hz}, 1 \mathrm{H}), 6.90$ $(\mathrm{dd}, J=8.4, J=1.8 \mathrm{~Hz}, 2 \mathrm{H}), 6.86(\mathrm{dd}, J=8.2, J=3.4 \mathrm{~Hz}, 1 \mathrm{H}), 6.79-6.77(\mathrm{~m}, 1 \mathrm{H}), 6.74-6.69(\mathrm{~m}, 2 \mathrm{H}), 5.14$ $(\mathrm{d}, J=2.2 \mathrm{~Hz}, 2 \mathrm{H}), 5.12(\mathrm{~s}, 2 \mathrm{H}), 4.49(\mathrm{~s}, 1 \mathrm{H}), 4.21(\mathrm{~s}, 1 \mathrm{H}), 3.36-3.28(\mathrm{~m}, 2 \mathrm{H}), 2.67(\mathrm{t}, J=7.8 \mathrm{~Hz}, 1 \mathrm{H})$, 
$2.61(\mathrm{t}, J=7.1 \mathrm{~Hz}, 1 \mathrm{H}) .{ }^{13} \mathrm{C} \mathrm{NMR}\left(\mathrm{CDCl}_{3}\right): \delta 154.5(\mathrm{C}), 154.3(\mathrm{C}), 148.4(\mathrm{q}, J=21.9 \mathrm{~Hz}, \mathrm{C}), 137.1(\mathrm{C})$, 137.0 (C), 136.9 (C), $130.4\left(\mathrm{CH}_{2}\right), 129.9$ (C), 129.8 (C), 129.5 (C), 128.6 (CHx2), 128.5 (CHx2), $128.0(\mathrm{CH}), 127.9(\mathrm{CH}), 127.7(\mathrm{C}), 127.4(\mathrm{CHx} 2), 127.3(\mathrm{CHx}), 121.4(\mathrm{CH}), 120.8\left(\mathrm{CF}_{3}\right), 115.8$ (CHx2), 115.6 (CHx2), $115.5(\mathrm{CH}), 115.1(\mathrm{CH}), 114.9(\mathrm{CH}), 114.5(\mathrm{CH}), 71.4\left(\mathrm{CH}_{2}\right), 71.3\left(\mathrm{CH}_{2}\right), 71.2$ $\left(\mathrm{CH}_{2}\right), 49.4\left(\mathrm{CH}_{2}\right), 48.2\left(\mathrm{CH}_{2}\right), 41.2\left(\mathrm{CH}_{2}\right), 34.3\left(\mathrm{CH}_{2}\right), 34.1\left(\mathrm{CH}_{2}\right), 31.9\left(\mathrm{CH}_{2}\right), 29.7\left(\mathrm{CH}_{2}\right)$. HRMS calc'd for $\mathrm{C}_{31} \mathrm{H}_{28} \mathrm{~F}_{3} \mathrm{NNaO}_{4}(\mathrm{M}+\mathrm{Na})^{+}$: 558.1863 , found 558.1863 .

\subsection{Compound 3h}

88\%, oil; ${ }^{1} \mathrm{H}$ NMR ( $\left.\mathrm{CDCl}_{3}\right): \delta 7.43-7.23(\mathrm{~m}, 5 \mathrm{H}), 6.96-6.91(\mathrm{~m}, 3 \mathrm{H}), 6.83-6.71(\mathrm{~m}, 4 \mathrm{H}), 5.93(\mathrm{~d}, J=8.3$ $\mathrm{Hz}, 1 \mathrm{H}), 5.04(\mathrm{~d}, J=4.2 \mathrm{~Hz}, 2 \mathrm{H}), 4.61(\mathrm{~s}, 1 \mathrm{H}), 4.35(\mathrm{~s}, 1 \mathrm{H}), 3.48-3.42(\mathrm{~m}, 2 \mathrm{H}), 2.79-2.70(\mathrm{~m}, 2 \mathrm{H}) .{ }^{13} \mathrm{C}$ NMR (CDCl $): \delta 159.3$ (C), 157.4 (C) (q, $J=33.9$ Hz, C), 155.0 (C), 154.8 (C), 136.8 (C), 136.7 (C), 136.6 (C), 136.3 (C), 130.2 (C), $130.1(\mathrm{C}), 129.9$ (CHx2), 129.8 (CHx2), $129.0(\mathrm{CH}), 128.7(\mathrm{CH})$, 128.2 (CHx2), 128.1 (CHx2), 127.5 (CHx2), $120.6(\mathrm{CH}), 120.0\left(\mathrm{CF}_{3}\right), 115.8(\mathrm{CHx} 2), 115.7$ (CHx2), $114.7(\mathrm{CHx} 2), 114.6(\mathrm{CHx} 2), 114.2(\mathrm{CH}), 70.2\left(\mathrm{CH}_{2}\right), 70.1\left(\mathrm{CH}_{2}\right), 51.52\left(\mathrm{CH}_{2}\right), 51.49\left(\mathrm{CH}_{2}\right), 49.8$ $\left(\mathrm{CH}_{2}\right), 48.7\left(\mathrm{CH}_{2}\right), 34.3\left(\mathrm{CH}_{2}\right), 31.9\left(\mathrm{CH}_{2}\right)$. HRMS calc'd for $\mathrm{C}_{24} \mathrm{H}_{22} \mathrm{~F}_{3} \mathrm{NNaO}_{3}(\mathrm{M}+\mathrm{Na})^{+}$: 452.1444 , found 452.1448 .

\subsection{Compound 3j}

77\%, oil; ${ }^{1} \mathrm{H}$ NMR $\left(\mathrm{CDCl}_{3}\right): \delta$ 7.33-7.28 (m, 1H), 7.15-7.07 (m, 1H), 6.98-6.9 (m, 2H), 6.78-6.74 (m,

2H), $4.60(\mathrm{~s}, 1 \mathrm{H}), 4.37(\mathrm{~s}, 1 \mathrm{H}), 3.51-3.45(\mathrm{~m}, 2 \mathrm{H}), 2.79(\mathrm{t}, J=7.8 \mathrm{~Hz}, 1 \mathrm{H}), 2.70(\mathrm{t}, J=7.2 \mathrm{~Hz}, 1 \mathrm{H}) .{ }^{13} \mathrm{C}$ NMR (CDCl $): \delta 157.0(\mathrm{C})(\mathrm{q}, J=38.1 \mathrm{~Hz}, \mathrm{C}), 154.8(\mathrm{C}), 154.6(\mathrm{C}), 135.9$ (C), 135.7 (C), 130.0 (CHx2), 129.9 (CHx2), $129.8(\mathrm{C}), 129.2(\mathrm{C}), 127.5(\mathrm{CH}), 127.2(\mathrm{CH}), 126.9(\mathrm{CH}), 126.7(\mathrm{CH}), 123.8$ $(\mathrm{CH}), 123.6\left(\mathrm{CF}_{3}\right), 115.7(\mathrm{CHx} 2), 115.6(\mathrm{CHx} 2), 48.6\left(\mathrm{CH}_{2}\right), 47.1\left(\mathrm{CH}_{2}\right), 47.0\left(\mathrm{CH}_{2}\right), 45.2\left(\mathrm{CH}_{2}\right)$, 34.4 $\left(\mathrm{CH}_{2}\right), 32.0\left(\mathrm{CH}_{2}\right)$. HRMS calc'd for $\mathrm{C}_{15} \mathrm{H}_{14} \mathrm{~F}_{3} \mathrm{NNaO}_{2} \mathrm{~S}(\mathrm{M}+\mathrm{Na})^{+}:$352.0590, found 352.0595. 


\subsection{Compound 31}

95\%, oil; ${ }^{1} \mathrm{H}$ NMR $\left(\mathrm{CDCl}_{3}\right): \delta$ 7.88-7.84 (m, 1H), 7.72-7.70 (m, 1H), 7.41-7.36 (m, 2H), $7.30(\mathrm{~s}, 1 \mathrm{H})$, 6.95-6.92 (m, 2H), 6.77-6.73 (m, 2H), 5.29 (broad s, 1H), $4.89(\mathrm{~s}, 1 \mathrm{H}), 4.60(\mathrm{~s}, 1 \mathrm{H}), 3.52(\mathrm{t}, J=7.1 \mathrm{~Hz}$, 1H), $3.46(\mathrm{t}, J=7.1 \mathrm{~Hz}, 1 \mathrm{H}), 2.80-2.73(\mathrm{~m}, 2 \mathrm{H}) .{ }^{13} \mathrm{C} \mathrm{NMR}\left(\mathrm{CDCl}_{3}\right): \delta 156.9(\mathrm{q}, J=85.6 \mathrm{~Hz}, \mathrm{C}) 154.8$ (C), 154.7 (C), 140.7 (C), 140.5 (C), 137.6 (C), 137.3 (C), 130.0 (CHx2), 129.9 (CHx2), 129.8 (C), $129.6(\mathrm{C}), 129.1(\mathrm{C}), 126.0(\mathrm{CH}), 125.0(\mathrm{CH}), 124.7(\mathrm{CH}), 124.6(\mathrm{CH}), 123.2(\mathrm{CH}), 123.1(\mathrm{CH}), 121.6$ $(\mathrm{CH}), 120.9(\mathrm{CH}), 118.1(\mathrm{CH}), 115.8(\mathrm{CHx} 2), 115.6(\mathrm{CHx} 2), 49.0\left(\mathrm{CH}_{2}\right),, 48.2\left(\mathrm{CH}_{2}\right), 46.3\left(\mathrm{CH}_{2}\right)$, $46.2\left(\mathrm{CH}_{2}\right), 43.6\left(\mathrm{CH}_{2}\right), 34.5\left(\mathrm{CH}_{2}\right), 32.2\left(\mathrm{CH}_{2}\right)$. HRMS calc'd for $\mathrm{C}_{19} \mathrm{H}_{16} \mathrm{~F}_{3} \mathrm{NNaO}_{2} \mathrm{~S}(\mathrm{M}+\mathrm{Na})^{+}$: 402.0746, found 402.0752.

\subsection{General procedure for the synthesis of compounds 4a-I}

To a dry flask containing $1.2 \mathrm{mmol}$ of a selected coupling precursor 3a-l in $6 \mathrm{~mL}$ of 2,2,2trifluoroethanol under argon were added $0.5956 \mathrm{~g}(1.4 \mathrm{mmol})$ phenyliodine bis(trifluoroacetate $)$ in dissolved in $6 \mathrm{~mL}$ of 2,2,2-trifluoroethanol. The reaction was stirred at $-40{ }^{\circ} \mathrm{C}$ for $30 \mathrm{~min}$ and the solution was concentrated in vacuo. Purification by column chromatography (hexanes/ethyl acetate, 2:1) yielded pure spirodienone $\mathbf{4 a - l}$. The NMR spectral data for known compounds $\left(\mathbf{4 a} \mathbf{a}^{50} \mathbf{4 b}^{50}\right.$ and $4 e^{50}$ ) matched those in the literature. The characterization of all new compounds is given below.

\subsection{Compound 4c}

36\%, white solid, mp: $71-73{ }^{\circ} \mathrm{C}$ (decomp.); ${ }^{1} \mathrm{H}$ NMR $\left(\mathrm{CDCl}_{3}\right): \delta 7.00(\mathrm{~d}, J=10.1 \mathrm{~Hz}, 1 \mathrm{H}), 6.88(\mathrm{~d}$, $J=10.1 \mathrm{~Hz}, 1 \mathrm{H}), 6.81(\mathrm{~s}, 1 \mathrm{H}), 6.65(\mathrm{~s}, 1 \mathrm{H}), 6.55(\mathrm{~s}, 1 \mathrm{H}), 6.24(\mathrm{~d}, J=9.9 \mathrm{~Hz}, 1 \mathrm{H}), 6.22(\mathrm{~d}, J=9.9 \mathrm{~Hz}$ $1 \mathrm{H}), 4.69(\mathrm{~d}, J=6.6 \mathrm{~Hz}, 2 \mathrm{H}), 4.19-4.14(\mathrm{~m}, 4 \mathrm{H}), 3.92-3.86(\mathrm{~m}, 2 \mathrm{H}), 2.31(\mathrm{tt}, J=17.5 \mathrm{~Hz}, 6.2 \mathrm{~Hz}, 2 \mathrm{H})$.

${ }^{13} \mathrm{C} \mathrm{NMR}\left(\mathrm{CDCl}_{3}\right): \delta 185.3(\mathrm{C}), 185.2(\mathrm{C}), 156.4$ (q, J=44.7 Hz, C), $152.8(\mathrm{CHx} 2), 152.3(\mathrm{CHx} 2)$, 
$143.4(\mathrm{C}), 143.3(\mathrm{C}), 142.8(\mathrm{C}), 129.0(\mathrm{C}), 128.9(\mathrm{C}), 128.5\left(\mathrm{CH}_{2}\right), 128.4\left(\mathrm{CH}_{2}\right), 127.2\left(\mathrm{CF}_{3}\right), 127.0$ (CF), $120.2(\mathrm{CH}), 118.9(\mathrm{CH}), 118.6(\mathrm{CH}), 64.4\left(\mathrm{CH}_{2}\right), 64.3\left(\mathrm{CH}_{2}\right), 48.7\left(\mathrm{CH}_{2}\right), 48.5\left(\mathrm{CH}_{2}\right), 48.2(\mathrm{C})$, $47.9\left(\mathrm{CH}_{2}\right), 45.6\left(\mathrm{CH}_{2}\right), 45.5\left(\mathrm{CH}_{2}\right), 44.3\left(\mathrm{CH}_{2}\right), 36.1\left(\mathrm{CH}_{2}\right), 33.9\left(\mathrm{CH}_{2}\right)$. HRMS calc'd for $\mathrm{C}_{19} \mathrm{H}_{16} \mathrm{~F}_{3} \mathrm{NNaO}_{4}(\mathrm{M}+\mathrm{Na})^{+}$: 402.0924, found 402.0926.

\subsection{Compound 4d}

26\%, white solid, mp: $147-149{ }^{\circ} \mathrm{C}$ (decomp.): ${ }^{1} \mathrm{H}$ NMR $\left(\mathrm{CDCl}_{3}\right): \delta 6.99(\mathrm{~d}, J=10.3 \mathrm{~Hz}, 1 \mathrm{H}), 6.86(\mathrm{~d}$, $J=10.3 \mathrm{~Hz}, 1 \mathrm{H}), 6.65-6.54(\mathrm{~m}, 2 \mathrm{H}), 6.26-6.22(\mathrm{~m}, 2 \mathrm{H}), 5.98(\mathrm{~d}, J=14.1 \mathrm{~Hz}, 2 \mathrm{H}), 4.85(\mathrm{~d}, J=15.4 \mathrm{~Hz}$, 2H), 3.95-3.91 (m, 2H), 2.37-2.31 (m, 2H). ${ }^{13} \mathrm{C}$ NMR (CDCl $): \delta 185.3(\mathrm{C}), 185.1(\mathrm{C}), 156.5(\mathrm{q}$, $J=104.5 \mathrm{~Hz}, \mathrm{C}), 152.5$ (CHx2), 152.2 (CHx2), 146.9 (C), 146.7 (C), 146.5 (C), 146.0 (C), 129.9 (C), $129.8(\mathrm{C}), 127.1(\mathrm{CHx}), 126.9(\mathrm{CHx} 2), 123.5(\mathrm{C}), 123.1(\mathrm{CH}), 117.8\left(\mathrm{CF}_{3}\right), 117.3\left(\mathrm{CF}_{3}\right), 108.3(\mathrm{CH})$, $108.1(\mathrm{CH}), 101.7\left(\mathrm{CH}_{2}\right), 101.6\left(\mathrm{CH}_{2}\right), 48.4(\mathrm{C}), 48.0(\mathrm{C}), 44.6\left(\mathrm{CH}_{2}\right), 41.0\left(\mathrm{CH}_{2}\right), 36.2\left(\mathrm{CH}_{2}\right), 34.2$ $\left(\mathrm{CH}_{2}\right)$. HRMS calc'd for $\mathrm{C}_{18} \mathrm{H}_{14} \mathrm{~F}_{3} \mathrm{NNaO}_{4}(\mathrm{M}+\mathrm{Na})^{+}: 388.0767$, found 388.0773 .

\subsection{Compound $4 f$}

41\%, white solid, mp: $109-111{ }^{\circ} \mathrm{C}$ (decomp.): ${ }^{1} \mathrm{H}$ NMR $\left(\mathrm{CDCl}_{3}\right): \delta 7.32-7.24(\mathrm{~m}, 5 \mathrm{H}), 6.85(\mathrm{~d}, J=10.0$ $\mathrm{Hz}, 1 \mathrm{H}), 6.76$ (d, $J=13.4 \mathrm{~Hz}, 1 \mathrm{H}), 6.70$ (d, $J=35.9 \mathrm{~Hz}, 1 \mathrm{H}), 6.47$ (d, $J=2.6 \mathrm{~Hz}, 1 \mathrm{H}), 6.17$ (dd, $J=10.1$, $J=3.1 \mathrm{~Hz}, 2 \mathrm{H}), 5.00(\mathrm{~s}, 2 \mathrm{H}), 4.73(\mathrm{~d}, J=14.6 \mathrm{~Hz}, 2 \mathrm{H}), 3.88(\mathrm{~s}, 3 \mathrm{H}), 3.86(\mathrm{~s}, 2 \mathrm{H}), 2.33-2.27(\mathrm{~m}, 2 \mathrm{H}) .{ }^{13} \mathrm{C}$ NMR (CDCl $): \delta 185.1$ (C),185.0 (C),156.4 (q, J=36.6 Hz, C), 152.7 (CHx2), 152.3 (CHx2), 148.8 (C), 147.6 (C), 147.5 (C), 136.6 (C), 136.5 (C), 128.7 (CHx2), 128.6 (CHx2), 128.3 (C), 128.1 (C), 128.0 (CHx2), 127.8 (CHx2), 127.6 (CH), 127.4 (C), $127.3\left(\mathrm{CF}_{3}\right), 127.2$ (CHx2), 127.1 (CHx2), 116.1 $(\mathrm{CH}), 114.5(\mathrm{CH}), 113.5(\mathrm{CH}), 71.3\left(\mathrm{CH}_{2}\right), 71.2\left(\mathrm{CH}_{2}\right), 56.2\left(\mathrm{CH}_{2}\right), 56.1\left(\mathrm{CH}_{2}\right), 48.3(\mathrm{C}), 48.2(\mathrm{C})$, $48.0(\mathrm{C}), 44.2\left(\mathrm{CH}_{3}\right), 35.5\left(\mathrm{CH}_{2}\right), 33.6\left(\mathrm{CH}_{2}\right)$. HRMS calc'd for $\mathrm{C}_{25} \mathrm{H}_{22} \mathrm{~F}_{3} \mathrm{NNaO}_{4}(\mathrm{M}+\mathrm{Na})^{+}:$: 480.1393, found 480.1398 . 


\subsection{Compound 4g}

20\%, white solid, mp: $79-79{ }^{\circ} \mathrm{C} ;{ }^{1} \mathrm{H}$ NMR $\left(\mathrm{CDCl}_{3}\right): \delta 7.43-7.24(\mathrm{~m}, 10 \mathrm{H}), 6.87(\mathrm{~d}, J=9.4 \mathrm{~Hz}, 1 \mathrm{H}), 6.76$ (d, $J=10.0 \mathrm{~Hz}, 1 \mathrm{H}), 6.63(\mathrm{~s}, 1 \mathrm{H}), 6.50(\mathrm{~d}, J=1.6 \mathrm{~Hz}, 1 \mathrm{H}), 6.19(\mathrm{dd}, J=9.9 \mathrm{~Hz}, J=6.72 \mathrm{H}), 5.19(\mathrm{~s}, 2 \mathrm{H})$, $5.01(\mathrm{~d}, J=2.4 \mathrm{~Hz}, 2 \mathrm{H}), 4.67(\mathrm{~d}, J=14.2 \mathrm{~Hz}, 2 \mathrm{H}), 3.89-3.84(\mathrm{~m}, 2 \mathrm{H}), 2.32-2.26(\mathrm{~m}, 2 \mathrm{H}) .{ }^{13} \mathrm{C}$ NMR $\left(\mathrm{CDCl}_{3}\right): \delta 185.2(\mathrm{C}), 185.1(\mathrm{C}), 152.7$ (CHx2), 152.3 (CHx2), $148.3(\mathrm{C}), 148.1$ (q, J=44.7 Hz, C), 136.7 (Cx2), 136.6 (Cx2), 128.6 (CHx4), 128.5 (CHx4), $128.4(\mathrm{C}), 128.3(\mathrm{C}), 128.2$ (CHx2), 128.1 (CHx2), $128.0(\mathrm{C}), 127.4(\mathrm{CHx} 2), 127.3\left(\mathrm{CF}_{3}\right), 127.1(\mathrm{CHx} 4), 117.1(\mathrm{CH}), 117.0(\mathrm{CH}), 116.8(\mathrm{CH})$, 116.6 (CH), $71.4\left(\mathrm{CH}_{2}\right), 71.4\left(\mathrm{CH}_{2}\right), 71.3\left(\mathrm{CH}_{2}\right), 71.2\left(\mathrm{CH}_{2}\right), 48.3\left(\mathrm{CH}_{2}\right), 48.2\left(\mathrm{CH}_{2}\right), 48.0(\mathrm{C}), 44.2$ $\left(\mathrm{CH}_{2}\right), 35.5\left(\mathrm{CH}_{2}\right), 33.6\left(\mathrm{CH}_{2}\right), 29.7\left(\mathrm{CH}_{2}\right)$. HRMS calc'd for $\mathrm{C}_{31} \mathrm{H}_{26} \mathrm{~F}_{3} \mathrm{NNaO}_{4}(\mathrm{M}+\mathrm{Na})^{+}$: 556.1712, found 556.1715 .

\subsection{Compound $4 h$}

21\%, white solid, mp: 58-58.5 ${ }^{\circ} \mathrm{C} ;{ }^{1} \mathrm{H}$ NMR $\left(\mathrm{CDCl}_{3}\right): \delta$ 7.39-7.30 (m, 5H), 7.02-6.95 (m, 3H), $6.89(\mathrm{~d}$, $J=10.2 \mathrm{~Hz}, 1 \mathrm{H}), 6.82-6.77(\mathrm{~m}, 1 \mathrm{H}), 6.29-6.25(\mathrm{~m}, 2 \mathrm{H}), 5.02(\mathrm{~s}, 2 \mathrm{H}), 4.78(\mathrm{~d}, J=8.0 \mathrm{~Hz}, 2 \mathrm{H}), 3.96-3.90$ $(\mathrm{m}, 2 \mathrm{H}), 2.38-2.31(\mathrm{~m}, 2 \mathrm{H}) .{ }^{13} \mathrm{C} \mathrm{NMR}\left(\mathrm{CDCl}_{3}\right): \delta 185.3(\mathrm{C}), 185.2(\mathrm{C}), 158.2(\mathrm{C}), 158.1(\mathrm{C}), 156.5(\mathrm{q}$, $J=77.8 \mathrm{~Hz}, \mathrm{C}), 152.8$ (CHx2), 152.4 (CHx2), 136.7 (C), 136.5 (C), 136.4 (C), 131.7 (C), $131.2(\mathrm{CH})$, 128.7 (CHx2), $128.2(\mathrm{CH}), 128.1(\mathrm{CH}), 127.5$ (CHx2), 127.4 (CHx2), 127.3 (CHx2), 127.1 (CHx2), $117.8\left(\mathrm{CF}_{3}\right), 117.0(\mathrm{CH}), 114.8(\mathrm{CH}), 114.7(\mathrm{CH}), 70.2\left(\mathrm{CH}_{2}\right), 70.1\left(\mathrm{CH}_{2}\right), 49.3\left(\mathrm{CH}_{2}\right), 49.1\left(\mathrm{CH}_{2}\right)$, $48.2(\mathrm{C}), 47.9(\mathrm{C}), 45.6\left(\mathrm{CH}_{2}\right), 45.5\left(\mathrm{CH}_{2}\right), 44.5\left(\mathrm{CH}_{2}\right), 36.1\left(\mathrm{CH}_{2}\right), 34.0\left(\mathrm{CH}_{2}\right)$. HRMS calc'd for $\mathrm{C}_{24} \mathrm{H}_{20} \mathrm{~F}_{3} \mathrm{NNaO}_{3}(\mathrm{M}+\mathrm{Na})^{+}:$450.1287, found 450.1292 .

\subsection{Compound $4 i$}


11\%, white solid, mp: $74-76{ }^{\circ} \mathrm{C} ;{ }^{1} \mathrm{H}$ NMR $\left(\mathrm{CDCl}_{3}\right): \delta$ 7.31-7.29 (m, 3H), 7.24-7.15 (m, 3H), 6.95-6.77 (m, 4H), 6.08 (d, $J=10.0 \mathrm{~Hz}, 2 \mathrm{H}), 4.86(\mathrm{~s}, 2 \mathrm{H}), 4.84(\mathrm{~s}, 2 \mathrm{H}), 3.88-3.81(\mathrm{~m}, 2 \mathrm{H}), 2.34-2.31(\mathrm{~m}, 2 \mathrm{H}) .{ }^{13} \mathrm{C}$ NMR (CDCl): $\delta 185.0$ (C), $158.4(\mathrm{C}), 156.4$ (q, J=92.9 Hz, C), 153.5 (CHx2), 153.3 (CHx2), 137.4 (C), $137.3(\mathrm{C}), 135.4(\mathrm{C}), 135.3(\mathrm{C}), 129.1(\mathrm{CH}), 128.6(\mathrm{CHx} 2), 128.3(\mathrm{CH}), 127.9(\mathrm{CHx} 2), 127.4$ (CHx2), $125.3(\mathrm{C}), 125.0(\mathrm{C}), 123.8(\mathrm{CH}), 122.9\left(\mathrm{CF}_{3}\right), 112.6(\mathrm{CH}), 112.5(\mathrm{CH}), 70.9\left(\mathrm{CH}_{2}\right), 48.8$ $\left(\mathrm{CH}_{2}\right), 47.8\left(\mathrm{CH}_{2}\right), 47.4\left(\mathrm{CH}_{2}\right), 47.1\left(\mathrm{CH}_{2}\right), 45.2\left(\mathrm{CH}_{2}\right), 45.1\left(\mathrm{CH}_{2}\right), 44.2\left(\mathrm{CH}_{2}\right), 38.4(\mathrm{C}), 37.0(\mathrm{C})$.

\subsection{Compound 41}

41\%, light yellow solid, mp: 89-92 ${ }^{\circ} \mathrm{C}$ (decomp.); ${ }^{1} \mathrm{H}$ NMR $\left(\mathrm{CDCl}_{3}\right): \delta 7.84(\mathrm{~d}, J=8.1,1 \mathrm{H}), 7.71(\mathrm{t}$, $J=7.8 \mathrm{~Hz}, 1 \mathrm{H}), 7.63(\mathrm{~d}, J=8.1 \mathrm{~Hz}, 1 \mathrm{H}), 7.43-7.31(\mathrm{~m} .2 \mathrm{H}), 7.13-7.11(\mathrm{~m}, 1 \mathrm{H}), 7.02-6.99(\mathrm{~m}, 1 \mathrm{H}), 6.36-$ $6.32(\mathrm{~m}, 2 \mathrm{H}), 5.05(\mathrm{~s}, 1 \mathrm{H}), 4.98(\mathrm{~s}, 1 \mathrm{H}), 4.11-4.08(\mathrm{~m}, 2 \mathrm{H}), 2.45-2.39(\mathrm{~m}, 2 \mathrm{H}) .{ }^{13} \mathrm{C}$ NMR $\left(\mathrm{CDCl}_{3}\right): \delta$ 184.7 (C), 156.5 (q, J=58.0 Hz, C), 150.0 (CHx2), 149.5 (CHx2), 140.2 (C), 139.5 (C), 138.8 (C), $138.3(\mathrm{C}), 137.8(\mathrm{C}), 130.3(\mathrm{C}), 129.8(\mathrm{C}), 128.6(\mathrm{CHx} 2), 128.4(\mathrm{CHx} 2), 125.3(\mathrm{CH}), 125.0(\mathrm{CH})$, $124.8(\mathrm{CH}), 122.6(\mathrm{CH}), 122.4(\mathrm{CH}), 121.4(\mathrm{CH}), 121.0\left(\mathrm{CF}_{3}\right), 46.0\left(\mathrm{CH}_{2}\right), 45.7\left(\mathrm{CH}_{2}\right), 45.6\left(\mathrm{CH}_{2}\right)$, $45.0\left(\mathrm{CH}_{2}\right), 42.8\left(\mathrm{CH}_{2}\right), 41.9\left(\mathrm{CH}_{2}\right), 37.5(\mathrm{C}), 35.7(\mathrm{C})$. HRMS calc'd for $\mathrm{C}_{23} \mathrm{H}_{26} \mathrm{~F}_{3} \mathrm{NNaO}_{2} \mathrm{~S}(\mathrm{M}+\mathrm{Na})^{+}$: 400.0590 , found 400.0593 .

\subsection{General procedure for the synthesis of compounds 5a-I}

To a flask containing $0.15 \mathrm{mmol}$ of a selected spirodienone $\mathbf{4 a}-\mathbf{m}$ in $0.78 \mathrm{~mL}$ of methanol were added $0.8 \mathrm{~mL}$ of $10 \%$ aqueous potassium hydroxide at room temperature. The reaction was stirred for $30 \mathrm{~min}$ and the solution was extracted several times with chloroform. The organic layers were collected, filtered, and concentrated in vacuo. Purification by column chromatography (chloroform/methanol, 14:1) yielded the desired 5,10b-ethanophenanthridine 5a-5l. The NMR spectral data for known 
compounds $\left(\mathbf{5} \mathbf{a}^{54}\right.$ and $\left.\mathbf{5} \mathbf{b}^{54}\right)$ matched those in the literature. The characterization of all new compounds is given below.

\subsection{Compound 5c}

66\%, white solid, mp: 151-153 ${ }^{\circ} \mathrm{C}$ (decomp.); ${ }^{1} \mathrm{H}$ NMR $\left(\mathrm{CDCl}_{3}\right): \delta 7.60(\mathrm{~d}, \mathrm{~J}=10.3 \mathrm{~Hz}, 1 \mathrm{H}), 6.87$ (s, 1H), $6.53(\mathrm{~s}, 1 \mathrm{H}), 6.05$ (d. J=10.3 Hz, 1H), 4.35 (d, J=16.9 Hz, 1H), 4.23-4.19 (m, 4H), $3.77(\mathrm{~d}, \mathrm{~J}=17.0$ Hz, 1H), 3.60 (dd, J=13.0 Hz, 5.7 Hz, 1H), 3.54-3.47 (m, 1H), 3.02-2.95 (m, 1H), 2.65 (dd, J=16.8 Hz, $5.7 \mathrm{~Hz}, 1 \mathrm{H}), 2.44$ (dd, J=16.7 Hz, 13.0 Hz, 1H), 2.37-2.31 (m, 1H), 2.18-2.10 (m, 1H). 13C NMR $\left(\mathrm{CDCl}_{3}\right): \delta 198.2(\mathrm{C}), 149.6(\mathrm{CH}), 142.3(\mathrm{C}), 142.1(\mathrm{C}), 136.0(\mathrm{C}), 128.7(\mathrm{CH}), 126.1(\mathrm{C}), 115.7(\mathrm{CH})$, $110.7(\mathrm{CH}), 68.9(\mathrm{CH}), 64.5\left(\mathrm{CH}_{2}\right), 64.4\left(\mathrm{CH}_{2}\right), 61.3\left(\mathrm{CH}_{2}\right), 54.0\left(\mathrm{CH}_{2}\right), 44.6(\mathrm{C}), 44.3\left(\mathrm{CH}_{2}\right), 40.1$ $\left(\mathrm{CH}_{2}\right)$. HRMS calc'd for $\mathrm{C}_{17} \mathrm{H}_{18} \mathrm{NO}_{3}(\mathrm{M}+\mathrm{H})+:$ 284.1281, found 284.1287.

\subsection{Compound 5d}

53\%, white solid, mp: $155-157{ }^{\circ} \mathrm{C}$ (decomp.); ${ }^{1} \mathrm{H}$ NMR $\left(\mathrm{CDCl}_{3}\right): \delta 7.65$ (d, J=10.3 Hz, $\left.1 \mathrm{H}\right), 6.84(\mathrm{~d}$, $J=10.3 \mathrm{~Hz}, 1 \mathrm{H}), 6.67(\mathrm{~d}, J=10.3 \mathrm{~Hz}, 1 \mathrm{H}), 6.05(\mathrm{~d}, J=10.3 \mathrm{~Hz}, 1 \mathrm{H}), 5.92(\mathrm{~d}, J=8.8 \mathrm{~Hz}, 1 \mathrm{H}), 4.30$ (d, $J=17.4 \mathrm{~Hz}, 1 \mathrm{H}), 3.85(\mathrm{~d}, J=17.4 \mathrm{~Hz}, 1 \mathrm{H}), 3.62-3.51(\mathrm{~m}, 2 \mathrm{H}), 3.04-2.97(\mathrm{~m}, 1 \mathrm{H}), 2.70(\mathrm{dd}, J=16.8 \mathrm{~Hz}$,

$5.6 \mathrm{~Hz}, 1 \mathrm{H}), 2.47(\mathrm{dd}, J=16.8 \mathrm{~Hz}, 13.0 \mathrm{~Hz}, 1 \mathrm{H}), 2.37-2.31(\mathrm{~m}, 1 \mathrm{H}), 2.22-2.14(\mathrm{~m}, 1 \mathrm{H}) .{ }^{13} \mathrm{C}$ NMR $\left(\mathrm{CDCl}_{3}\right): \delta 198.0(\mathrm{C}), 149.5(\mathrm{CH}), 145.8(\mathrm{C}), 145.1(\mathrm{C}), 137.3(\mathrm{C}), 128.5(\mathrm{CH}), 114.8(\mathrm{C}), 114.3(\mathrm{CH})$, $106.4(\mathrm{CH}), 101.4(\mathrm{CH} 2), 68.8(\mathrm{CH}), 56.9\left(\mathrm{CH}_{2}\right), 54.3\left(\mathrm{CH}_{2}\right), 44.8(\mathrm{C}), 44.7\left(\mathrm{CH}_{2}\right), 40.1\left(\mathrm{CH}_{2}\right) . \mathrm{HRMS}$ calc'd for $\mathrm{C}_{16} \mathrm{H}_{16} \mathrm{NO}_{3}(\mathrm{M}+\mathrm{H})^{+}: 270.1125$, found 270.1130 .

\subsection{Compound 5e}

74\%, white solid, mp: 149-151 ${ }^{\circ} \mathrm{C}$ (decomp.); ${ }^{1} \mathrm{H} \mathrm{NMR}\left(\mathrm{CDCl}_{3}\right): \delta 7.73$ (d, $\left.J=10.2 \mathrm{~Hz}, 1 \mathrm{H}\right), 7.44$ (d, $J=7.0 \mathrm{~Hz}, 2 \mathrm{H}), 7.39(\mathrm{t}, J=7.2 \mathrm{~Hz}, 2 \mathrm{H}), 7.33(\mathrm{~d}, J=6.6 \mathrm{~Hz}, 1 \mathrm{H}), 6.95(\mathrm{~s}, 1 \mathrm{H}), 6.60(\mathrm{~s}, 1 \mathrm{H}), 6.13(\mathrm{~d}$, 
$J=10.2 \mathrm{~Hz}, 1 \mathrm{H}), 5.11(\mathrm{~s}, 2 \mathrm{H}), 4.39(\mathrm{~d}, J=8.4 \mathrm{~Hz}, 1 \mathrm{H}), 3.93(\mathrm{~s}, 3 \mathrm{H}), 3.79(\mathrm{~d}, J=8.4 \mathrm{~Hz}, 1 \mathrm{H}), 3.66$ (dd, $J=5.5, J=6.4 \mathrm{~Hz}, 1 \mathrm{H}), 3.56(\mathrm{t}, J=12.2 \mathrm{~Hz}, 1 \mathrm{H}), 3.06-2.99(\mathrm{~m}, 1 \mathrm{H}), 2.73-2.65(\mathrm{~m}, 1 \mathrm{H}), 2.50$ (t, $J=14.8$ $\mathrm{Hz}, 1 \mathrm{H}) 2.41(\mathrm{t}, J=9.0 \mathrm{~Hz}, 1 \mathrm{H}) 2.19-2.12(\mathrm{~m}, 1 \mathrm{H}) .{ }^{13} \mathrm{C} \mathrm{NMR}\left(\mathrm{CDCl}_{3}\right): 198.1(\mathrm{C}), 149.5(\mathrm{CH}), 148.4$ (C), $147.4(\mathrm{C}), 137.0(\mathrm{C}), 135.5(\mathrm{C}), 128.8(\mathrm{CHx} 2), 128.6(\mathrm{CH}), 127.9(\mathrm{CH} 2), 127.3(\mathrm{C}), 125.3(\mathrm{CH})$, $112.9(\mathrm{CH}), 106.4(\mathrm{CH}), 71.1(\mathrm{CH}), 68.9\left(\mathrm{CH}_{2}\right), 61.5\left(\mathrm{CH}_{2}\right) 56.5\left(\mathrm{CH}_{3}\right), 54.1\left(\mathrm{CH}_{2}\right), 44.8(\mathrm{C}), 44.5$ $\left(\mathrm{CH}_{2}\right), 40.2\left(\mathrm{CH}_{2}\right)$. HRMS calc'd for $\mathrm{C}_{23} \mathrm{H}_{24} \mathrm{NO}_{3}(\mathrm{M}+\mathrm{H})+:$ 362.1751, found 362.1753 .

\subsection{Compound $5 f$}

30\%, white solid, mp: 67-69 ${ }^{\circ} \mathrm{C}$ (decomp.); ${ }^{1} \mathrm{H}$ NMR $\left(\mathrm{CDCl}_{3}\right): \delta 7.54(\mathrm{~d}, J=10.4 \mathrm{~Hz}, 1 \mathrm{H}), 7.46(\mathrm{~d}$, $\mathrm{J}=7.2 \mathrm{~Hz}, 2 \mathrm{H}), 7.38-7.33(\mathrm{~m}, 1 \mathrm{H}), 6.93(\mathrm{~s}, 1 \mathrm{H}), 6.58(\mathrm{~s}, 1 \mathrm{H}), 6.06(\mathrm{~d}, J=10.4 \mathrm{~Hz}, 1 \mathrm{H}), 5.14(\mathrm{~s}, 2 \mathrm{H})$, 4.43, (d, $J=8.5 \mathrm{~Hz}, 1 \mathrm{H}), 3.64$ (s, 3H), 3.83 (d, $J=8.4 \mathrm{~Hz}, 1 \mathrm{H}), 3.64$ (dd, $J=5.7, J=6.5 \mathrm{~Hz}, 1 \mathrm{H}), 3.55-3.52$ (m, 1H), 3.03-2.99 (m, 1H), 2.68 (dd, $J=5.6, J=8.4 \mathrm{~Hz}, 1 \mathrm{H}), 2.74$ (dd, $J=13.0, J=8.4 \mathrm{~Hz}, 1 \mathrm{H}) 2.34-2.30$ (m, 1H), 2.18-2.14 (m, 1H). ${ }^{13} \mathrm{C}$ NMR $\left(\mathrm{CDCl}_{3}\right): \delta 198.1(\mathrm{C}), 149.5(\mathrm{CH}), 149.0(\mathrm{C}), 146.8(\mathrm{C}), 137.1$ (C), $134.8(\mathrm{C}), 128.8(\mathrm{CHx} 2), 128.6(\mathrm{CH}), 128.0(\mathrm{CHx} 2), 127.5(\mathrm{C}), 126.2(\mathrm{CH}), 110.8(\mathrm{CH}), 109.3$ $(\mathrm{CH}), 72.0(\mathrm{CH}), 69.0\left(\mathrm{CH}_{2}\right), 62.0\left(\mathrm{CH}_{2}\right), 56.1\left(\mathrm{CH}_{3}\right), 54.1\left(\mathrm{CH}_{2}\right), 44.8(\mathrm{C}), 44.3\left(\mathrm{CH}_{2}\right), 40.2\left(\mathrm{CH}_{2}\right)$. HRMS calc'd for $\mathrm{C}_{23} \mathrm{H}_{24} \mathrm{NO}_{3}(\mathrm{M}+\mathrm{H})^{+}: 362.1751$, found 362.1756 .

\subsection{Compound 5g}

30\%, white solid, mp: $60-60.5{ }^{\circ} \mathrm{C} ;{ }^{1} \mathrm{H}$ NMR $\left(\mathrm{CDCl}_{3}\right): \delta 7.54(\mathrm{~d}, J=10.3 \mathrm{~Hz}, 1 \mathrm{H}), 7.43-7.24(\mathrm{~m}, 10 \mathrm{H})$, $6.96(\mathrm{~s}, 1 \mathrm{H}), 6.62(\mathrm{~s}, 1 \mathrm{H}), 6.06(\mathrm{~d}, J=10.3 \mathrm{~Hz}, 1 \mathrm{H}), 5.13(\mathrm{~s}, 2 \mathrm{H}), 5.08$ (s, 1H), $4.34(\mathrm{~d}, J=8.4 \mathrm{~Hz}, 1 \mathrm{H})$, $3.79(\mathrm{~d}, J=8.4 \mathrm{~Hz}, 1 \mathrm{H}), 3.66-3.61(\mathrm{~m}, 1 \mathrm{H}), 3.59-3.52(\mathrm{~m}, 1 \mathrm{H}), 3.01-2.98(\mathrm{~m}, 1 \mathrm{H}), 2.71$ (dd, $J=16.84$, $J=2.86 \mathrm{~Hz}, 1 \mathrm{H}), 2.50(\mathrm{dd}, J=13.02, J=8.38 \mathrm{~Hz}, 1 \mathrm{H}), 2.34-2.30(\mathrm{~m}, 1 \mathrm{H}), 2.18-2.13(\mathrm{~m}, 1 \mathrm{H}) .{ }^{13} \mathrm{C} \mathrm{NMR}$ ( $\left.\mathrm{CDCl}_{3}\right): 197.8(\mathrm{C}), 149.1(\mathrm{CH}), 148.4(\mathrm{C}), 147.5(\mathrm{C}), 137.2(\mathrm{C}), 137.0(\mathrm{C}), 135.3(\mathrm{C}), 128.9$ (CHx2), $128.6(\mathrm{CHx} 2), 128.0(\mathrm{CHx} 2), 127.9(\mathrm{CHx} 2), 127.5(\mathrm{C}+\mathrm{CHx} 2), 127.3(\mathrm{CH}), 113.5(\mathrm{CH}), 110.3(\mathrm{CH})$, 
$72.3(\mathrm{CH}), 71.2\left(\mathrm{CH}_{2}\right), 68.8\left(\mathrm{CH}_{2}\right), 61.3\left(\mathrm{CH}_{2}\right), 54.0\left(\mathrm{CH}_{2}\right), 44.5(\mathrm{C}), 39.9\left(\mathrm{CH}_{2}\right), 29.7\left(\mathrm{CH}_{2}\right)$. HRMS calc'd for $\mathrm{C}_{29} \mathrm{H}_{28} \mathrm{NO}_{3}(\mathrm{M}+\mathrm{H})^{+}$: 438.2064, found 438.2068 .

\subsection{Compound 5h}

40\%, white solid, mp: $103-105{ }^{\circ} \mathrm{C}$ (decomp.); ${ }^{1} \mathrm{H}$ NMR $\left(\mathrm{CDCl}_{3}\right): \delta 7.70$ (d, $\left.J=10.4 \mathrm{~Hz}, 1 \mathrm{H}\right), 7.41-7.29$ (m, 6H), $6.81(\mathrm{dd}, J=8.6, J=2.6 \mathrm{~Hz}, 1 \mathrm{H}), 6.67$ (d, $J=1.3 \mathrm{~Hz}, 1 \mathrm{H}), 6.07$ (d, $J=10.3 \mathrm{~Hz}, 1 \mathrm{H}), 5.01(\mathrm{~s}, 2 \mathrm{H})$, $4.43(\mathrm{~d}, J=8.6 \mathrm{~Hz}, 1 \mathrm{H}), 3.85(\mathrm{~d}, J=8.6 \mathrm{~Hz}, 1 \mathrm{H}), 3.63(\mathrm{dd}, J=5.4, J=3.8 \mathrm{~Hz}, 1 \mathrm{H}), 3.60-3.50(\mathrm{~m}, 1 \mathrm{H})$, 3.04-2.97 (m, 1H), $2.66(\mathrm{dd}, J=8.4, J=5.8 \mathrm{~Hz}, 1 \mathrm{H}), 2.47$ (dd, $J=13.0, J=8.4 \mathrm{~Hz}, 1 \mathrm{H}), 2.38-2.31(\mathrm{~m}, 1 \mathrm{H})$, 2.20-2.16 (m, 1H). ${ }^{13} \mathrm{C}$ NMR (CDCl 3$): \delta 198.2(\mathrm{C}), 157.6(\mathrm{C}), 149.7(\mathrm{CH}), 136.9(\mathrm{C}), 135.4(\mathrm{C}), 135.0$ (C), $128.7(\mathrm{CHx} 2), 128.6(\mathrm{CH}), 128.0(\mathrm{CHx} 2), 127.4(\mathrm{CH}), 122.7(\mathrm{CH}), 113.4(\mathrm{CH}), 113.1(\mathrm{CH}), 70.1$ (CH), $69.0\left(\mathrm{CH}_{2}\right), 62.0\left(\mathrm{CH}_{2}\right), 54.2\left(\mathrm{CH}_{2}\right), 44.8(\mathrm{C}), 44.4\left(\mathrm{CH}_{2}\right), 40.2\left(\mathrm{CH}_{2}\right)$. HRMS calc'd for $\mathrm{C}_{22} \mathrm{H}_{22} \mathrm{NO}_{2}(\mathrm{M}+\mathrm{H})^{+}: 332.1645$, found 332.1650 .

\subsection{Compound 5i}

45\%, white solid, mp: $62-63{ }^{\circ} \mathrm{C} ;{ }^{1} \mathrm{H}$ NMR $\left(\mathrm{CDCl}_{3}\right): \delta 8.64(\mathrm{~d}, J=10.6 \mathrm{~Hz}, 1 \mathrm{H}), 7.40-7.33(\mathrm{~m}, 5 \mathrm{H}), 7.11$ (t, $J=7.8 \mathrm{~Hz}, 1 \mathrm{H}), 6.81(\mathrm{~d}, J=8.2 \mathrm{~Hz}, 1 \mathrm{H}), 6.65(\mathrm{~d}, J=7.5 \mathrm{~Hz}, 1 \mathrm{H}), 5.89$ (d, $J=10.6 \mathrm{~Hz}, 1 \mathrm{H}), 5.12$ (s, 2H), $4.48(\mathrm{~d}, J=8.6 \mathrm{~Hz}, 1 \mathrm{H}), 3.76(\mathrm{~d}, J=8.6 \mathrm{~Hz}, 1 \mathrm{H}), 3.69-3.62(\mathrm{~m}, 2 \mathrm{H}), 3.57-3.50(\mathrm{~m}, 1 \mathrm{H}), 2.97-2.89$ (m, 1H), $2.65(\mathrm{dd}, J=16.9, J=2.8 \mathrm{~Hz}, 1 \mathrm{H}), 2.52-2.41(\mathrm{~m}, 1 \mathrm{H}), 2.22-2.15(\mathrm{~m}, 1 \mathrm{H}) .{ }^{13} \mathrm{C}$ NMR $\left(\mathrm{CDCl}_{3}\right): \delta$ $198.3(\mathrm{C}), 155.7(\mathrm{C}), 153.0(\mathrm{CH}), 139.6(\mathrm{C}), 135.9(\mathrm{C}), 131.0(\mathrm{CH}), 129.4(\mathrm{CH}), 128.9(\mathrm{CH}), 128.8$ $(\mathrm{CH}), 128.2(\mathrm{CH}), 127.7(\mathrm{CH}), 127.6(\mathrm{CH}), 127.5(\mathrm{C}), 119.9(\mathrm{CH}), 111.0(\mathrm{CH}), 70.7(\mathrm{CH}), 69.7\left(\mathrm{CH}_{2}\right)$, $61.9\left(\mathrm{CH}_{2}\right), 54.2\left(\mathrm{CH}_{2}\right), 46.0\left(\mathrm{CH}_{2}\right), 43.4(\mathrm{C}), 40.5\left(\mathrm{CH}_{2}\right)$. HRMS calc'd for $\mathrm{C}_{22} \mathrm{H}_{22} \mathrm{NO}_{2}(\mathrm{M}+\mathrm{H})^{+}$: 332.1645 , found 332.1650 .

\subsection{Compound 5j}


40\%, white solid, mp: $114-116{ }^{\circ} \mathrm{C}$ (decomposes); ${ }^{1} \mathrm{H}$ NMR $\left(\mathrm{CDCl}_{3}\right): \delta 7.34$ (d, $\left.J=10.0 \mathrm{~Hz}, 1 \mathrm{H}\right), 7.10$ (d, $J=5.0 \mathrm{~Hz}, 1 \mathrm{H}), 6.75(\mathrm{~d}, J=5.0 \mathrm{~Hz}, 1 \mathrm{H}), 6.07(\mathrm{~d}, J=10.0 \mathrm{~Hz}, 1 \mathrm{H}), 4.31(\mathrm{~d}, J=8.3 \mathrm{~Hz}, 1 \mathrm{H}), 3.80$ (d, $J=8.3 \mathrm{~Hz}, 1 \mathrm{H}), 3.67(\mathrm{dd}, J=12.7, J=2.8 \mathrm{~Hz}, 1 \mathrm{H}), 3.61-3.55(\mathrm{~m}, 1 \mathrm{H}), 3.04-2.97(\mathrm{~m}, 1 \mathrm{H}), 2.74(\mathrm{dd}$, $J=19.9, J=5.8 \mathrm{~Hz}, 1 \mathrm{H}), 2.55-2.43(\mathrm{~m}, 2 \mathrm{H}), 2.21-2.13(\mathrm{~m}, 1 \mathrm{H}) .{ }^{13} \mathrm{C} \mathrm{NMR}\left(\mathrm{CDCl}_{3}\right): \delta 197.7(\mathrm{C}), 145.0$ $(\mathrm{CH}), 142.6(\mathrm{C}), 131.9(\mathrm{C}), 129.3(\mathrm{CH}), 126.2(\mathrm{CH}), 122.7(\mathrm{CH}), 70.2(\mathrm{CH}), 59.1\left(\mathrm{CH}_{2}\right), 54.2\left(\mathrm{CH}_{2}\right)$, 45.6 $\left(\mathrm{CH}_{2}\right), 45.1(\mathrm{C}), 40.1\left(\mathrm{CH}_{2}\right)$. HRMS calc'd for $\mathrm{C}_{13} \mathrm{H}_{14} \mathrm{NOS}(\mathrm{M}+\mathrm{H})^{+}: 232.0791$, found 232.0796.

\subsection{Compound 5k}

45\%, white solid, mp: $118-119{ }^{\circ} \mathrm{C}$ (decomp.); ${ }^{1} \mathrm{H}$ NMR $\left(\mathrm{CDCl}_{3}\right): \delta 7.53(\mathrm{~d}, J=10.2 \mathrm{~Hz}, 1 \mathrm{H}), 7.06(\mathrm{~d}$, $J=2.8 \mathrm{~Hz}, 1 \mathrm{H}), 6.94(\mathrm{~d}, J=2.8 \mathrm{~Hz}, 1 \mathrm{H}), 6.07$ (d, $J=10.2 \mathrm{~Hz}, 1 \mathrm{H}), 4.31$ (d, $J=8.4 \mathrm{~Hz}, 1 \mathrm{H}), 3.94$ (d, J=8.4 $\mathrm{Hz}, 1 \mathrm{H}), 3.58-3.47(\mathrm{~m}, 2 \mathrm{H}), 3.01-2.97(\mathrm{~m}, 1 \mathrm{H}), 2.73(\mathrm{dd}, J=5.7, \mathrm{~J}=8.4 \mathrm{~Hz}, 1 \mathrm{H}), 2.49$ (t, $J=13.0, J=8.4$ $\mathrm{Hz}, 1 \mathrm{H}), 2.31-2.28(\mathrm{~m}, 1 \mathrm{H}), 2.22-2.17(\mathrm{~m}, 1 \mathrm{H}) .{ }^{13} \mathrm{C} \mathrm{NMR}\left(\mathrm{CDCl}_{3}\right): \delta 197.8(\mathrm{C}), 149.7(\mathrm{CH}), 144.8(\mathrm{C})$, $133.9(\mathrm{C}), 128.7(\mathrm{CH}), 120.7(\mathrm{CH}), 115.4(\mathrm{CH}), 69.2(\mathrm{CH}), 58.4\left(\mathrm{CH}_{2}\right), 53.5\left(\mathrm{CH}_{2}\right), 46.1(\mathrm{C}), 43.3$ $\left(\mathrm{CH}_{2}\right), 39.7\left(\mathrm{CH}_{2}\right)$. HRMS calc'd for $\mathrm{C}_{13} \mathrm{H}_{14} \mathrm{NOS}(\mathrm{M}+\mathrm{H})^{+}: 232.0791$, found 232.0796 .

\subsection{Compound 51}

74\%, light yellow solid, mp: 143-145 ${ }^{\circ} \mathrm{C}$ (decomp.); ${ }^{1} \mathrm{H}$ NMR $\left(\mathrm{CDCl}_{3}\right): \delta 7.82(\mathrm{~d}, J=7.4 \mathrm{~Hz}, 1 \mathrm{H}), 7.46$ (d, $J=7.4 \mathrm{~Hz}, 1 \mathrm{H}), 7.38-7.30$ (m. 2H), 6.11 (d, $J=10.0 \mathrm{~Hz}, 1 \mathrm{H}), 4.44$ (d, $J=16.6 \mathrm{~Hz}, 1 \mathrm{H}), 3.96(\mathrm{~d}$, $J=16.6 \mathrm{~Hz}, 1 \mathrm{H}), 3.80(\mathrm{dd}, J=12.9 \mathrm{~Hz}, 5.8 \mathrm{~Hz}, 1 \mathrm{H}), 3.67-3.60(\mathrm{~m}, 1 \mathrm{H}), 3.09-3.01(\mathrm{~m}, 1 \mathrm{H}), 2.78$ (dd,

$J=17.0 \mathrm{~Hz}, 5.6 \mathrm{~Hz}, 1 \mathrm{H}), 2.66-2.59(\mathrm{~m}, 2 \mathrm{H}), 2.52(\mathrm{dd}, J=16.9 \mathrm{~Hz}, 13.0 \mathrm{~Hz}, 1 \mathrm{H}), 2.25-2.18(\mathrm{~m}, 1 \mathrm{H}) .{ }^{13} \mathrm{C}$ NMR ( $\left.\mathrm{CDCl}_{3}\right): \delta 197.7(\mathrm{C}), 149.7(\mathrm{CH}), 138.3(\mathrm{C}), 129.6(\mathrm{C}), 126.1(\mathrm{C}), 124.6(\mathrm{C}), 124.2(\mathrm{CH}), 122.9$ $(\mathrm{CH}), 120.8(\mathrm{CH}), 70.7(\mathrm{CH}), 58.1(\mathrm{CH}), 54.6\left(\mathrm{CH}_{2}\right), 45.9\left(\mathrm{CH}_{2}\right), 45.0(\mathrm{C}), 40.3\left(\mathrm{CH}_{2}\right), 29.3\left(\mathrm{CH}_{2}\right)$. HRMS calc'd for $\mathrm{C}_{17} \mathrm{H}_{16} \mathrm{NOS}(\mathrm{M}+\mathrm{H})^{+}$: 282.0947, found 282.0952 . 


\subsection{Preparation of compound $4 \mathrm{~m}$ :}

This spirodienone was prepared by debenzylation of $\mathbf{4 e}$ as described in the literature. ${ }^{51}$ Its NMR spectral data matched those in the cited report.

\subsection{Preparation of compound 5m}

This compound was prepared by detrifluoroacetylation of $\mathbf{4 m}$ as described in the literature. ${ }^{51}$ Its NMR spectral data matched those in the cited report.

\subsection{Preparation of compound $5 n$}

To a dry flask containing $10.8 \mathrm{mg}(0.040 \mathrm{mmol})$ of $\mathbf{5 m}$ in $0.3 \mathrm{~mL}$ of pyridine under nitrogen were added $20 \mu \mathrm{L}(0.17 \mathrm{mmol})$ of benzoyl chloride and the reaction was allowed to stir for 2 days at room temperature. The mixture was quenched with $0.2 \mathrm{~mL}$ methanol and concentrated in vacuo. The crude was redissolved in chloroform and washed once with saturated sodium bicarbonate. The organic layer was filtered and concentrated in vacuo. Purification by preparative TLC (chloroform/methanol, 15:1) yielded benzoate $5 n\left(8.3 \mathrm{mg}, 56 \%\right.$ ) as a white solid (mp: $205-207{ }^{\circ} \mathrm{C}$ (decomp.)). ${ }^{1} \mathrm{H}$ NMR $\left(\mathrm{CDC}_{3}\right): \delta$ $8.20(\mathrm{~d}, J=8.0 \mathrm{~Hz}, 2 \mathrm{H}), 7.73(\mathrm{~d}, J=10.0 \mathrm{~Hz}, 1 \mathrm{H}), 7.61(\mathrm{t}, J=8.3 \mathrm{~Hz}, 1 \mathrm{H}), 7.52(\mathrm{t}, J=8.0 \mathrm{~Hz}, 2 \mathrm{H}), 7.05(\mathrm{~s}$, 1H), $6.88(\mathrm{~s}, 1 \mathrm{H}), 6.15(\mathrm{~d}, J=10.0 \mathrm{~Hz}, 1 \mathrm{H}), 4.46(\mathrm{~d}, J=8.4 \mathrm{~Hz}, 1 \mathrm{H}), 3.89-3.85(\mathrm{~m}, 4 \mathrm{H}), 3.74$ (dd, $J=5.0$, $J=6.6 \mathrm{~Hz}, 1 \mathrm{H}), 3.61(\mathrm{t}, J=12.4 \mathrm{~Hz}, 1 \mathrm{H}), 3.09-3.06(\mathrm{~m}, 1 \mathrm{H}), 2.75(\mathrm{dd}, J=5.0, J=8.2 \mathrm{~Hz}, 1 \mathrm{H}), 2.57-2.46$ (m, 2H), 2.28-2.23 (m, 1H). ${ }^{13} \mathrm{C}$ NMR $\left(\mathrm{CDCl}_{3}\right): \delta 197.9(\mathrm{C}), 164.8(\mathrm{C}), 150.0(\mathrm{CH}), 149.0(\mathrm{C}), 141.1$ (C), 138.9 (C), $133.6(\mathrm{CH}), 130.3$ (CHx2), 129.2 (C), 129.0 (CHx2), $128.6(\mathrm{CH}), 125.4(\mathrm{C}), 121.8$ $(\mathrm{CH}), 106.5(\mathrm{CH}), 68.6(\mathrm{CH}), 61.0\left(\mathrm{CH}_{2}\right), 56.2\left(\mathrm{CH}_{3}\right), 54.1\left(\mathrm{CH}_{2}\right), 44.9(\mathrm{C}), 44.7\left(\mathrm{CH}_{2}\right), 40.0\left(\mathrm{CH}_{2}\right)$. HRMS calc'd for $\mathrm{C}_{23} \mathrm{H}_{22} \mathrm{NO}_{4}(\mathrm{M}+\mathrm{H})^{+}$: 376.1549, found 376.1546.

\subsection{Preparation of compound 5o}


To a dry flask containing $3.0 \mathrm{mg}(0.011 \mathrm{mmol})$ of $\mathbf{5 m}$ in $1.0 \mathrm{~mL}$ DMF under nitrogen were added 1.8 $\mu \mathrm{L}(0.016 \mathrm{mmol})$ of 5-hexynoic acid, $3.4 \mathrm{mg}(0.016 \mathrm{mmol})$ of DCC and $1.0 \mathrm{mg}(0.008 \mathrm{mmol})$ of DMAP at $\mathrm{r}$. t. The reaction was stirred at $\mathrm{rt}$ for $20 \mathrm{~h}$. The reaction mixture was diluted with water and extracted with ethyl acetate and the organic layer was washed with sat. $\mathrm{NaHCO}_{3}$ solution and water, dried over anhydrous $\mathrm{Na}_{2} \mathrm{SO}_{4}$ and concentrated under vacuo. The crude product was purified by preparative TLC (chloroform/methanol, 24:1) and obtained pure $\mathbf{5 0}(3.1 \mathrm{mg}, 76 \%)$ as a white solid (mp: 58-61 ${ }^{\circ} \mathrm{C}$ (decomp.)). ${ }^{1} \mathrm{H}$ NMR $\left(400 \mathrm{MHz}, \mathrm{CDCl}_{3}\right) \delta 7.67$ (d, J=10.3 Hz, 1H), 6.99 (s, 1H), 6.76 (s, 1H), $6.14(\mathrm{~d}, J=10.3 \mathrm{~Hz}, 1 \mathrm{H}), 4.46(\mathrm{~d}, J=16.7 \mathrm{~Hz}, 1 \mathrm{H}), 3.92-3.84(\mathrm{~m}, 4 \mathrm{H}), 3.73$ (dd, $J=13.1,5.7$ Hz, 1H), $3.69-3.59(\mathrm{~m}, 1 \mathrm{H}), 3.13-3.01(\mathrm{~m}, 1 \mathrm{H}), 2.85-2.75(\mathrm{~m}, 1 \mathrm{H}), 2.72(\mathrm{t}, J=7.3 \mathrm{~Hz}, 2 \mathrm{H}), 2.59-$ $2.40(\mathrm{~m}, 2 \mathrm{H}), 2.36(\mathrm{td}, J=7.0,2.7 \mathrm{~Hz}, 2 \mathrm{H}), 2.29-2.19(\mathrm{~m}, 1 \mathrm{H}), 2.01(\mathrm{t}, J=2.7 \mathrm{~Hz}, 1 \mathrm{H}), 1.98(\mathrm{t}, J=7.1$ Hz, 2H). ${ }^{13} \mathrm{C}$ NMR (100 MHz, $\left.\mathrm{CDCl}_{3}\right) \delta 197.3(\mathrm{C}), 171.3(\mathrm{C}), 150.0(\mathrm{CH}), 148.6(\mathrm{C}), 148.5(\mathrm{C}), 140.8$ (C), $138.9(\mathrm{CH}), 129.3(\mathrm{C}), 121.8(\mathrm{CH}), 106.6(\mathrm{CH}), 83.3(\mathrm{C}), 69.4(\mathrm{CH}), 68.7(\mathrm{CH}), 60.9\left(\mathrm{CH}_{2}\right), 56.3$ $\left(\mathrm{CH}_{3}\right), 54.1\left(\mathrm{CH}_{2}\right), 45.0(\mathrm{C}), 44.4\left(\mathrm{CH}_{2}\right), 39.8\left(\mathrm{CH}_{2}\right), 32.8\left(\mathrm{CH}_{2}\right), 23.9\left(\mathrm{CH}_{2}\right), 17.9\left(\mathrm{CH}_{2}\right)$. HRMS

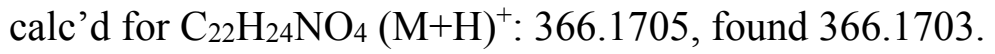

\subsection{Preparation of compound 5p}

To a dry flask containing $15.9 \mathrm{mg}(0.059 \mathrm{mmol})$ of $\mathbf{5 m}$ in $0.63 \mathrm{~mL}$ pyridine under argon were added 13 $\mu \mathrm{L}(0.14 \mathrm{mmol})$ of acetic anhydride at $0{ }^{\circ} \mathrm{C}$. The reaction was allowed to stir for $3.5 \mathrm{~h}$, at which point 7 $\mu \mathrm{L}(0.074 \mathrm{mmol})$ of acetic anhydride were added every hour for $2 \mathrm{~h}$. The reaction was quenched with methanol, concentrated in vacuo, and the crude was redissolved in chloroform. The solution was washed twice with water, twice with brine and the organic layer was filtered. Purification by preparative TLC (chloroform/methanol, 14:1) yielded acetate 5o (11.3 mg, 62\%) as a white solid (mp: 67-71 ${ }^{\circ} \mathrm{C}$ (decomp.)). ${ }^{1} \mathrm{H}$ NMR (CDC1 13$): \delta 7.63(\mathrm{~d}, J=10.5 \mathrm{~Hz}, 1 \mathrm{H}), 6.92(\mathrm{~s}, 1 \mathrm{H}), 6.67(\mathrm{~s}, 1 \mathrm{H}), 6.05(\mathrm{~d}$, $J=10.2 \mathrm{~Hz}, 1 \mathrm{H}), 4.34(\mathrm{~d}, J=8.3 \mathrm{~Hz}, 1 \mathrm{H}), 3.82-3.73(\mathrm{~m}, 4 \mathrm{H}), 3.61$ (dd, $J=5.4, J=6.4 \mathrm{~Hz}, 1 \mathrm{H}), 3.50(\mathrm{t}$, 
$J=11.2 \mathrm{~Hz}, 1 \mathrm{H}), 3.00-2.93(\mathrm{~m}, 1 \mathrm{H}), 2.64(\mathrm{dd}, J=5.1, \mathrm{~J}=8.0 \mathrm{~Hz}, 1 \mathrm{H}), 2.47-2.35(\mathrm{~m}, 2 \mathrm{H}), 2.24(\mathrm{~s}, 3 \mathrm{H})$, 2.17-2.10 (m, 1H). ${ }^{13} \mathrm{C}$ NMR $\left(\mathrm{CDCl}_{3}\right): \delta 197.8(\mathrm{C}), 169.1(\mathrm{C}), 149.7(\mathrm{CH}), 149.0(\mathrm{C}), 141.1(\mathrm{C}), 138.6$ (C), $129.0(\mathrm{CH}), 125.4(\mathrm{C}), 121.6(\mathrm{CH}), 106.4(\mathrm{CH}), 68.6(\mathrm{CH}), 60.9\left(\mathrm{CH}_{2}\right), 56.1\left(\mathrm{CH}_{3}\right), 54.1\left(\mathrm{CH}_{2}\right)$, $44.8(\mathrm{C}), 44.6\left(\mathrm{CH}_{2}\right), 30.9\left(\mathrm{CH}_{2}\right), 20.6\left(\mathrm{CH}_{3}\right)$. HRMS calc'd for $\mathrm{C}_{18} \mathrm{H}_{20} \mathrm{NO}_{4}(\mathrm{M}+\mathrm{H})^{+}: 314.1387$, found 314.1391.

\subsection{Preparation of compound 5q}

To a solution containing $10.5 \mathrm{mg}(0.039 \mathrm{mmol})$ of $\mathbf{5 m}$ in $0.5 \mathrm{~mL}$ of a pyridine/ethanol mixture (1:1) were added $5.5 \mathrm{mg}(0.042 \mathrm{mmol})$ of hydroxyl ammonium sulfate over a steam bath. The solution was stirred for $1 \mathrm{~h}$, at which point $9.6 \mathrm{mg}(0.073 \mathrm{mmol})$ of additional hydroxyl ammonium sulfate was added. The solution was stirred for an additional hour and concentrated in vacuo. The crude was redissolved in ethanol, filtered, and the supernatant was purified by column chromatography (chloroform/methanol, 10:1, adjusted with ammonium hydroxide to $\mathrm{pH}$ 8). Oxime $\mathbf{5 p}$ was isolated as a white solid (7.8 mg, 70\%, mp: $58-59{ }^{\circ} \mathrm{C}$ (decomp.)) as a mixture of geometric isomers. ${ }^{1} \mathrm{H}$ NMR $\left(\mathrm{CDC}_{3}\right): \delta 6.90(\mathrm{~s}, 1 \mathrm{H}), 6.88(\mathrm{~d}, J=10.4 \mathrm{~Hz}, 1 \mathrm{H}), 6.60(\mathrm{~s}, 1 \mathrm{H}), 6.25$ (d, $\left.J=10.4 \mathrm{~Hz}, 1 \mathrm{H}\right), 4.41(\mathrm{~d}, J=8.2$ $\mathrm{Hz}, 1 \mathrm{H}), 3.92$ (s, 3H), 3.84 (d, J=8.1 Hz, 1H), 3.65-3.32 (m, 3H), 2.97-2.92 (m, 1H), 2.29-2.04 (m, 3H). ${ }^{13} \mathrm{C}$ NMR $\left(\mathrm{CDCl}_{3}\right): \delta 155.3(\mathrm{C}), 145.2(\mathrm{CH}), 144.3(\mathrm{C}), 135.2(\mathrm{C}), 125.6(\mathrm{C}), 124.1(\mathrm{CH}), 123.1$ (C), $112.9(\mathrm{CH}), 105.1(\mathrm{CH}), 66.4(\mathrm{CH}), 61.4\left(\mathrm{CH}_{2}\right), 56.1\left(\mathrm{CH}_{3}\right), 53.1\left(\mathrm{CH}_{2}\right), 44.5(\mathrm{C}), 29.7\left(\mathrm{CH}_{2}\right)$, $24.3\left(\mathrm{CH}_{2}\right)$. HRMS calc'd for $\mathrm{C}_{16} \mathrm{H}_{19} \mathrm{~N}_{2} \mathrm{O}_{3}(\mathrm{M}+\mathrm{H})^{+}: 287.1396$, found 287.1394 .

\subsection{Preparation of compounds $5 \mathrm{r}$ and $5 \mathrm{~s}$}

To a flask containing $32.3 \mathrm{mg}(0.11 \mathrm{mmol})$ of benzothiophene $\mathbf{5 1}$ in $0.65 \mathrm{~mL}$ of dichloromethane under nitrogen were added $38 \mu \mathrm{L}$ of $30 \%$ hydrogen peroxide and $33 \mu \mathrm{L}$ of acetonitrile. After stirring for $1.5 \mathrm{~h}$ at room temperature, $1.4 \mathrm{~mL}$ dichloromethane and $0.4 \mathrm{~mL}$ trifluoroacetic acid under were added and 
the mixture was allowed to stir for 1 day. The reaction was quenched with ammonium hydroxide and the product was extracted with chloroform. The organic layers were collected, filtered and concentrated in vacuo. Purification by preparative TLC (chloroform/ methanol, 14:1) yielded sulfoxide 5q (11.6 mg, 34\%, mp: $149-151{ }^{\circ} \mathrm{C}$ (decomposes)) and sulfone 5r (6.7 mg, 19\%, mp: $143-145{ }^{\circ} \mathrm{C}$ (decomp.)) as white solids. 5q: ${ }^{1} \mathrm{H}$ NMR $\left(\mathrm{CDCl}_{3}\right): \delta 7.70(\mathrm{~d}, J=9.4 \mathrm{~Hz}, 1 \mathrm{H}), 7.66(\mathrm{~d}, J=17.1 \mathrm{~Hz}, 1 \mathrm{H})$, 7.62-7.47 (m. 2H), 7.16 (d, J=6.9 Hz, 1H), 6.12 (d, $J=10.2 \mathrm{~Hz}, 1 \mathrm{H}), 4.20$ (d, $J=18.6 \mathrm{~Hz}, 1 \mathrm{H}), 3.74$ (s, $1 \mathrm{H}), 3.69-3.60(\mathrm{~m}, 3 \mathrm{H}), 3.06-2.99(\mathrm{~m}, 1 \mathrm{H}), 2.92-2.86(\mathrm{~m}, 1 \mathrm{H}), 2.73(\mathrm{dd}, J=17.0 \mathrm{~Hz}, J=5.6 \mathrm{~Hz}, 1 \mathrm{H})$, 2.46 (dd, $J=16.9 \mathrm{~Hz}, 13.0 \mathrm{~Hz}, 1 \mathrm{H}), 2.24-2.17(\mathrm{~m}, 1 \mathrm{H}) .{ }^{13} \mathrm{C} \mathrm{NMR}\left(\mathrm{CDCl}_{3}\right): \delta 196.4(\mathrm{C}), 145.5(\mathrm{CH})$, $141.9(\mathrm{C}), 137.0(\mathrm{C}), 135.4(\mathrm{C}), 133.6(\mathrm{CH}), 130.3(\mathrm{CH}), 130.1(\mathrm{CH}), 121.4(\mathrm{CH}), 121.3(\mathrm{C}), 69.8$ $(\mathrm{CH}), 56.4(\mathrm{CH}), 55.1\left(\mathrm{CH}_{2}\right), 44.9\left(\mathrm{CH}_{2}\right), 44.3(\mathrm{C}), 41.0\left(\mathrm{CH}_{2}\right), 39.7\left(\mathrm{CH}_{2}\right)$. HRMS calc'd for $\mathrm{C}_{19} \mathrm{H}_{20} \mathrm{NO}_{2} \mathrm{~S}(\mathrm{M}+\mathrm{H})^{+}: 298.0896$, found 298.0905. 5r: ${ }^{1} \mathrm{H} \mathrm{NMR}\left(\mathrm{CDCl}_{3}\right): \delta 7.90(\mathrm{~d}, J=8.9 \mathrm{~Hz}, 1 \mathrm{H}), 7.71$ (d, $J=10.1 \mathrm{~Hz}, 1 \mathrm{H}), 7.52-7.41$ (m. 2H), 7.20 (d, $J=7.3 \mathrm{~Hz}, 1 \mathrm{H}), 6.12$ (d, $J=12.3 \mathrm{~Hz}, 1 \mathrm{H}), 4.23$ (d, $J=3.4$ $\mathrm{Hz}, 1 \mathrm{H}), 3.74(\mathrm{~s}, 1 \mathrm{H}), 3.70-3.60(\mathrm{~m}, 2 \mathrm{H}), 3.57-3.52(\mathrm{dd}, J=13.0 \mathrm{~Hz}, J=5.5 \mathrm{~Hz}, 1 \mathrm{H}), 3.11-3.04(\mathrm{~m}, 1 \mathrm{H})$, 2.91-2.85 (m, 1H), 2.73 (dd, $J=17.0 \mathrm{~Hz}, 5.6 \mathrm{~Hz}, 1 \mathrm{H}), 2.49$ (dd, $J=16.9 \mathrm{~Hz}, 13.0 \mathrm{~Hz}, 1 \mathrm{H}), 2.27-2.20$ (m, 1H). ${ }^{13} \mathrm{C}$ NMR $\left(\mathrm{CDCl}_{3}\right): \delta 197.2(\mathrm{C}), 150.5(\mathrm{CH}), 148.2(\mathrm{CH}), 145.2(\mathrm{C}), 139.4(\mathrm{C}), 136.8(\mathrm{C}), 132.2$ (C), $130.2(\mathrm{CH}), 128.7(\mathrm{CH}), 126.3(\mathrm{CH}), 121.5(\mathrm{CH}), 70.8(\mathrm{CH}), 57.4\left(\mathrm{CH}_{2}\right), 55.4\left(\mathrm{CH}_{2}\right), 45.1\left(\mathrm{CH}_{2}\right)$, $44.7(\mathrm{C}), 40.1\left(\mathrm{CH}_{2}\right)$. HRMS calc'd for $\mathrm{C}_{19} \mathrm{H}_{20} \mathrm{NO}_{3} \mathrm{~S}(\mathrm{M}+\mathrm{H})^{+}: 314.0846$, found 314.0875 .

\subsection{Preparation of compound 5t}

To a flask containing $48.3 \mathrm{mg}(0.17 \mathrm{mmol})$ of ketone $5 \mathbf{l}$ in $2.5 \mathrm{~mL}$ ethyl acetate and $2 \mathrm{~mL}$ methanol were added $0.1341 \mathrm{~g}(0.36 \mathrm{mmol})$ of cerium trichloride heptahydrate and $13.6 \mathrm{mg}(0.36 \mathrm{mmol})$ of sodium borohydride. The reaction mixture was stirred for $3.5 \mathrm{~h}$ at $0{ }^{\circ} \mathrm{C}$ and then filtered with through celite and the celite filter was washed with ethyl acetate and chloroform. The supernatant was concentrated in vacuo, dissolved in ethyl acetate, and washed with saturated sodium bicarbonate. The 
organic layer was then dried with sodium sulfate, filtered and concentrated in vacuo. Purification by column chromatography (chloroform/methanol, 15:1-10:1) yielded alcohol 5s (33.1 mg, 68\%) as a white solid (mp: 189-191 ${ }^{\circ} \mathrm{C}$ (decomp.)). ${ }^{1} \mathrm{H}$ NMR $\left(\mathrm{CDCl}_{3}\right): \delta 7.79(\mathrm{~d}, J=7.8 \mathrm{~Hz}, 1 \mathrm{H}), 7.42(\mathrm{~d}, J=7.5$ Hz, 1H), 7.33-7.24 (m. 2H), 6.19 (d, J=10.0 Hz, 1H), 5.80 (d, J=10.0 Hz, 1H), 4.52-4.49 (m, 1H), 4.46 $(\mathrm{d}, J=16.7 \mathrm{~Hz}, 1 \mathrm{H}), 3.92(\mathrm{~d}, J=16.5 \mathrm{~Hz}, 1 \mathrm{H}), 3.58-3.51(\mathrm{~m}, 1 \mathrm{H}), 3.43(\mathrm{dd}, J=13.3 \mathrm{~Hz}, J=3.6 \mathrm{~Hz}, 1 \mathrm{H})$, 3.22 (broad s, 1H), 2.99-2.92 (m, 1H), 2.47-2.40 (m, 1H), 2.29-2.24 (m, 1H), 2.19-2.12 (m, 1H), 1.73$1.64(\mathrm{~m}, 1 \mathrm{H}) .{ }^{13} \mathrm{C} \mathrm{NMR}\left(\mathrm{CDCl}_{3}\right): \delta 146.3(\mathrm{C}), 138.4(\mathrm{C}), 138.3(\mathrm{C}), 132.3(\mathrm{C}), 128.9(\mathrm{CH}), 124.7$ $(\mathrm{CH}), 124.3(\mathrm{CH}), 123.8(\mathrm{CH}), 122.9(\mathrm{CH}), 120.4(\mathrm{CH}), 68.5(\mathrm{CH}), 67.9(\mathrm{CH}), 58.4\left(\mathrm{CH}_{2}\right), 53.6$ $\left(\mathrm{CH}_{2}\right), 45.5(\mathrm{C}), 45.1\left(\mathrm{CH}_{2}\right), 34.6\left(\mathrm{CH}_{2}\right)$. HRMS calc'd for $\mathrm{C}_{17} \mathrm{H}_{18} \mathrm{NOS}(\mathrm{M}+\mathrm{H})^{+}:$: 284.1104, found 284.1109.

\subsection{Preparation of compound 5u}

To a dry flask containing $16.7 \mathrm{mg}(0.059 \mathrm{mmol})$ of alcohol $\mathbf{5 s}$ in $4 \mathrm{~mL}$ of dry THF were added $7.1 \mathrm{mg}$ $(0.18 \mathrm{mmol})$ of $60 \%$ sodium hydride dispersion in mineral oil. The reaction was allowed to stir at $0{ }^{\circ} \mathrm{C}$ for $1 \mathrm{~h}$ and $11 \mu \mathrm{L}(25.1 \mathrm{mg}, 0.18 \mathrm{mmol})$ of methyl iodide were added. The reaction mixture was stirred and allowed to warm to room temperature for $5.5 \mathrm{~h}$, at which point saturated ammonium chloride was used to quench the reaction. The mixture was filtered and the supernatant was concentrated in vacuo. The compound was dissolved in methanol and filtered again. The supernatant was concentrated in vacuo to yield methyl ether (16.1 mg, 92\%) as a white solid (mp: $231-233{ }^{\circ} \mathrm{C}$ (decomp.)) requiring no purification. ${ }^{1} \mathrm{H}$ NMR (MeOD): $\delta 7.90(\mathrm{~d}, J=8.3 \mathrm{~Hz}, 1 \mathrm{H}), 7.63$ (dd, $\left.J=7.0 \mathrm{~Hz}, 1.0 \mathrm{~Hz} 1 \mathrm{H}\right)$, 7.45-7.36 (m. 2H), $6.11(\mathrm{~d}, J=10.0 \mathrm{~Hz}, 2.2 \mathrm{~Hz}, 1 \mathrm{H}), 5.96$ (d, $J=10.2 \mathrm{~Hz}, 1 \mathrm{H}), 5.13(\mathrm{~s}, 2 \mathrm{H}), 4.49-4.45(\mathrm{~m}, 2 \mathrm{H})$, 4.13-4.08 (m, 2H), $3.48(\mathrm{~s}, 3 \mathrm{H}), 2.74-2.67(\mathrm{~m}, 1 \mathrm{H}), 2.65-2.53(\mathrm{~m}, 2 \mathrm{H}), 2.16-1.92(\mathrm{~m}, 1 \mathrm{H}) .{ }^{13} \mathrm{C}$ NMR (MeOD): $\delta 143.1(\mathrm{C}), 138.6(\mathrm{C}), 136.2(\mathrm{C}), 133.7$ (C), $124.9(\mathrm{CH}), 124.9(\mathrm{CH}), 124.5(\mathrm{CH}), 122.6$ 
$(\mathrm{CH}), 120.6(\mathrm{CH}), 119.6(\mathrm{CH}), 75.1(\mathrm{CH}), 68.0(\mathrm{CH}), 66.0\left(\mathrm{CH}_{2}\right), 63.6(\mathrm{C}), 42.1\left(\mathrm{CH}_{2}\right), 29.3\left(\mathrm{CH}_{2}\right)$. HRMS calc'd for $\mathrm{C}_{18} \mathrm{H}_{20} \mathrm{NOS}(\mathrm{M}+\mathrm{H})^{+}: 298.1260$, found 298.1269 .

\subsection{Preparation of compound 5v}

To a solution of $0.1657 \mathrm{~g}(0.46 \mathrm{mmol})$ of ketone $5 \mathbf{e}$ in $12.2 \mathrm{~mL}$ methanol were added $0.3583 \mathrm{~g}(0.96$ mmol) of cerium trichloride heptahydrate and $34.9 \mathrm{mg}(0.92 \mathrm{mmol})$ of sodium borohydride at $0{ }^{\circ} \mathrm{C}$. The solution was stirred for $1.5 \mathrm{~h}$ and filtered through celite. The solution was concentrated in vacuo and purified by column chromatography (chloroform/ methanol, 14:1) yielding alcohol 5v (0.1374 g, $82 \%$ ) as a white solid (mp: $189-191{ }^{\circ} \mathrm{C}$ (decomp.)). ${ }^{1} \mathrm{H}$ NMR (MeOD- $\left.d 4\right): \delta$ 7.41-7.27 (m, 5H), 7.00 (s, 1H), $6.79(\mathrm{~s}, 1 \mathrm{H}), 6.53(\mathrm{dd}, J=10.4, J=1.1 \mathrm{~Hz}, 1 \mathrm{H}), 5.83(\mathrm{~d}, J=10.4 \mathrm{~Hz}, 1 \mathrm{H}), 5.04(\mathrm{~s}, 2 \mathrm{H}), 4.65$ (d, $J=7.9 \mathrm{~Hz}, 1 \mathrm{H}), 4.41-4.36(\mathrm{~m}, 1 \mathrm{H}), 4.19$ (d, $J=7.9 \mathrm{~Hz}, 1 \mathrm{H}), 3.84(\mathrm{~s}, 3 \mathrm{H}), 3.82-3.74(\mathrm{~m}, 1 \mathrm{H}), 3.37-3.30$ (m, 1H), 2.34-2.24 (m, 3H), 1.781.70 (m, 1H), 1.12-1.10 (m, 1H). ${ }^{13} \mathrm{C} \mathrm{NMR}\left(\mathrm{CDCl}_{3}\right): \delta 149.3(\mathrm{C})$, $147.5(\mathrm{C}), 137.0(\mathrm{C}), 135.3(\mathrm{C}), 132.2(\mathrm{CH}), 128.1(\mathrm{CHx} 2), 127.6(\mathrm{CH}), 127.2(\mathrm{CH}), 125.8(\mathrm{CHx} 2)$, $119.2(\mathrm{C}), 112.8(\mathrm{CH}), 106.8(\mathrm{CH}), 70.8\left(\mathrm{CH}_{2}\right), 66.8(\mathrm{CH}), 65.7\left(\mathrm{CH}_{2}\right), 59.0(\mathrm{CH}), 55.4\left(\mathrm{CH}_{3}\right), 52.2$ $\left(\mathrm{CH}_{2}\right), 44.6(\mathrm{C}), 42.2\left(\mathrm{CH}_{2}\right), 31.9\left(\mathrm{CH}_{2}\right)$. HRMS calc'd for $\mathrm{C}_{23} \mathrm{H}_{26} \mathrm{NO}_{3}(\mathrm{M}+\mathrm{H})^{+}$: 364.1907, found 364.1912.

\subsection{Cell culture}

Human cancer cell lines were obtained from the American Type Culture Collection (ATCC, Manassas, VA, USA), the European Collection of Cell Culture (ECACC, Salisbury, UK) and the Deutsche Sammlung von Mikroorganismen und Zellkulturen (DSMZ, Braunschweig, Germany). Human cervical adenocarcinoma HeLa cells were cultured in DMEM supplemented with $10 \%$ fetal bovine serum (FBS). Human mammary carcinoma MCF-7 cells were cultured in RPMI supplemented with 10\% FBS. The U87 cells (ATCC HTB-14) were cultured in DMEM culture medium, while the 
A549 cells (DSMZ ACC107) were cultured in RPMI culture medium supplemented with $10 \%$ heatinactivated FBS. The GBM Hs683 (ATCC HTB-138) and the T98G (ATCC CRL-1690) cell lines were cultivated in DMEM supplemented with 10\% FBS. The GBM U251 cells (ECACC code 09063001) were cultured in 10\% MEM. The Human uterine sarcoma MES-SA and MES-SA/Dx5 cells were cultured in RPMI-1640 medium supplemented with 10\% FBS with MES SA/Dx5 maintained in the presence of $500 \mathrm{nM}$ Doxorubicin (Sigma). The U373 glioblastoma cells (ECACC 08061901) were cultured in RPMI culture medium supplemented with $10 \%$ heat-inactivated FBS. Cell culture media were supplemented with $4 \mathrm{mM}$ glutamine (Lonza code BE17-605E), $100 \mu \mathrm{g} / \mathrm{mL}$ gentamicin (Lonza code 17-5182), and penicillin-streptomycin (200 units $/ \mathrm{ml}$ and $200 \mu \mathrm{g} / \mathrm{ml}$ ) (Lonza code 17-602E). Primary GBM-derived neurosphere cultures from a patient undergoing surgical debulking were established using previously described methods. ${ }^{76}$ Briefly, resected tumor tissue was minced with a sterile scalpel and dissociated in $3 \mathrm{~mL}$ of neurobasal (NB) media containing $100 \mathrm{U} / \mathrm{mL}$ of collagenase (Life Technologies, USA) for 30 minutes at 37 degrees. Dissociated tissue was then vortexed and filtered using a sterile 70 um nylon Falcon cell strainer (Corning, NY, USA). The filtered fraction was centrifuged at $200 \mathrm{x}$ g for 5 minutes and the pellet was transferred to a Corning ultra-low attachment plate containing neurobasal medium (Invitrogen, Carlsbad, CA) supplemented with the following: B27 supplement (1X; Invitrogen), Glutamax (10ul/ml; Invitrogen), fibroblast growth factor-2 (20 ug/ml; Peprotech, Rocky Hill, NJ, USA), epidermal growth factor (20 ug/ml; Peprotech), heparin (32 ku/ml; Sigma Aldrich, St. Louis, MO) and penicillin-streptomycin (1X, Invitrogen). GBM 090909 and GBM 031810 cell lines were maintained in NB media containing supplements and media was renewed twice weekly. NSCLC cell lines H1993 and H2073 were obtained from the Hamon Center for Therapeutic Oncology Research at UT Southwestern Medical Center and cultured in RPMI-1640 medium (Mediatech, VA, USA) supplemented with 5\% heat-inactivated FBS (Mediatech, VA, USA), 100 
units $/ \mathrm{mL}$ penicillin and $0.1 \mathrm{mg} / \mathrm{mL}$ streptomycin (Sigma, MO, USA). All cell lines were cultured in T25 flasks, maintained and grown at $37^{\circ} \mathrm{C}, 95 \%$ humidity, $5 \% \mathrm{CO}_{2}$.

\subsection{Antiproliferative Properties}

Antiproliferative properties of the synthesized compounds were evaluated by the MTT assay. All compounds were dissolved in DMSO at a concentration of either $100 \mathrm{mM}$ or $50 \mathrm{mM}$ prior to cell treatment. The cells were trypsinized and seeded at various cell concentrations depending on the cell type. The cells were grown for $24 \mathrm{~h}$ to $72 \mathrm{~h}$, treated with compounds at concentrations ranging from 0.001 to $100 \mu \mathrm{M}$ and incubated for 48,72 or $96 \mathrm{~h}$ in 100 or $200 \mu \mathrm{L}$ media depending on the cell line used. The number of experiments and replicates varied depending on the cell line in Tables 1,2 and Figure 3. Cells treated with $0.1 \%$ DMSO were used as a negative control; $1 \mu \mathrm{M}$ phenyl arsine oxide (PAO) was used as a positive control.

\subsection{Selection of Doxorubicin Resistant Cells}

Selection of Doxorubicin Resistant Cells. Selection of the MES-SA/Dx5 cell line was done according to Harker et al. ${ }^{73}$ The cells were split and allowed to adhere overnight. The next day cells were initially exposed to a DOX concentration of $100 \mathrm{nM}$, which represented the $\mathrm{GI}_{50}$ concentration. The cells were maintained at this DOX concentration until their growth rate reached that of the untreated cells. The DOX concentration was then increased in two-fold increments following the same growth criteria at each concentration to a final DOX concentration of $500 \mathrm{nM}$. Each new DOX concentration required approximately 2 passages to reach the growth rate of the untreated cells. 


\subsection{Evaluation of synergism of compounds $4 \mathrm{l}$ and $5 \mathrm{I}$ with paclitaxel}

Paclitaxel (Teva, PA, USA) was dissolved in polyethoxylated castor oil. Compounds $\mathbf{4 l}$ and $\mathbf{5 l}$ were dissolved in DMSO. All compounds were diluted to different concentrations in medium. Appropriate numbers of cells ( 4 × $10^{3}$ cells per well for H1993, 7 x $10^{3}$ cells per well for H2073) were seeded into 96-well plates. The cells were grown for $24 \mathrm{~h}$ and treated with paclitaxel and either $\mathbf{4 l}$ or $\mathbf{5 l}$, alone or in combination. After 96 h, viability of cells was assessed using the CellTiter-Glo® Luminescent Cell Viability Assay (Promega, WI, USA), according to the manufacturer's instructions. Predicted additivity was calculated based on Bliss Independence, as defined by $E_{x y}=E_{x}+E_{y}-E_{x} E_{y}$, where $E_{x y}$ is the additive effect of drugs $\mathrm{x}$ and $\mathrm{y}$ as predicted by their individual effects $\mathrm{E}_{\mathrm{x}}$ and $\mathrm{E}_{\mathrm{y}}{ }^{77}$

\subsection{Quantitative Translation Assays.}

In vitro translation assays were performed as previously described. ${ }^{74}$ Polysome profiling was as previously documented. ${ }^{74}$ Antibodies for Western blots were directed to p-eIF2 $\alpha$, pan-eIF2 $\alpha$, and eEF2 (Cell Signaling Technology, MA).

\section{Acknowledgments}

This project was supported by grants from the National Institute of General Medical Sciences (P20GM103451), National Cancer Institute (CA186046-01A1), Welch Foundation (AI-0045), and National Science Foundation (NSF award 0946998). Work in J. Pelletier's lab is supported by grants from the Canadian Institutes of Health Research (MOP-106530, MOP-233466). SR, LF and ALP acknowledge their NMT Presidential Research Support. LF acknowledges Samantha Saville and National Science Foundation (NSF award IIA-1301346). XY, XM, and AP are grateful to the CPRIT 
Training Grant RP 140105. RK is a director of research with the Fonds National de la Recherche Scientifique (FRS-FNRS; Belgium).

\section{References}

1. Kelly, G. L; Strasser A. The essential role of evasion from cell death in cancer. Adv. Cancer Res. 2011, 111, 39-96

2. Kornienko, A.; Mathieu, V.; Rastogi, S.; Lefranc, F.; Kiss, R. Therapeutic Agents Triggering Non-Apoptotic Cancer Cell Death. J. Med. Chem. 2013, 56, 4823-4839.

3. Lefranc, F.; Brotchi, J.; Kiss, R. Possible future issues in the treatment of glioblastomas: special emphasis on cell migration and the resistance of migrating glioblastoma cells to apoptosis. $J$. Clin. Oncol. 2005, 23, 2411-2422.

4. Ellis, H. P; Greenslade, M.; Powell, B.; Spiteri, I.; Sottoriva, A.; Kurian, K. M. Current Challenges in Glioblastoma: Intratumour Heterogeneity, Residual Disease, and Models to Predict Disease Recurrence. Front. Oncol. 2015, 5, 251

5. Cancer Genome Atlas Research Networks (231 collaborators). Comprehensive genomic characterization defines human glioblastoma genes and core pathways. Nature 2013, 455, 1061-1068.

6. Agnihotri, S.; Burrell, K. E.; Wolf, A.; Jalali, S.; Hawkins, C.; Rutka, J. T.; Zadeh, G. Glioblastoma, a Brief Review of History, Molecular Genetics, Animal Models and Novel Therapeutic Strategies. Arch. Immunol. Ther. Exp. 2013, 61, 25-41.

7. Stupp, R.; Hottinger, A. F.; van den Bent, M. J.; Dietrich, P. Y.; Brandes, A. A. Frequently asked questions in the medical management of high-grade glioma: a short guide with practical answers. Ann. Oncol. 2008, 19 (Suppl 7), 209-216. 
8. Lefranc, F.; Sadeghi, N.; Camby, I.; Metens, T.; De Witte, O.; Kiss, R. Present and potential future issues in glioblastoma treatment. Expert Rev. Anticancer Ther. 2006, 6, 719-732.

9. Stupp, R.; Hegi, M. E.; Mason, W. P.; van den Bent, M. J.; Taphoorn, M. J.; Janzer, R. C.; Ludwin, S. K.; Allgeier, A.; Fisher, B.; Belanger, K.; Hau, P.; Brandes, A. .; Gijtenbeek, J.; Marosi, C.; Vecht, C. J.; Mokhtari, K.; Wesseling, P.; Villa, S.; Eisenhauer, E.; Gorlia, T.; Weller, M.; Lacombe, D.; Cairncross G.; Mirimanof, R. -O. Effects of radiotherapy with concomitant and adjuvant temozolomide versus radiotherapy alone on survival in glioblastoma in a randomised phase III study: 5-year analysis of the EORTC-NCIC trial Lancet Oncol. 2009, $10,459-466$.

10. Stupp, R.; Mason, W. P.; van den Bent, M. J.; Weller, M.; Fisher, B.; Taphoorn, M. J.; Belanger, K.; Brandes, A. A.; Marosi, C.; Bogdahn, U. Radiotherapy plus concomitant and adjuvant temozolomide for glioblastoma. N. Engl. J. Med. 2005, 352, 987-996.

11. Brenner, H. Long-term survival rates of cancer patients achieved by the end of the 20th century: a period analysis. The Lancet 2002, 360, 1131-1135.

12. Gottesman, M. M.; Fojo, T.; Bates, S. E. Multidrug resistance in cancer: Role of ATPdependent transporters. Nat. Rev. Cancer 2002, 2, 48-58.

13. Saraswathy, M.; Gong, S. Q. Different strategies to overcome multidrug resistance in cancer. Biotechnol. Adv. 2013, 31, 1397-1407.

14. Chen, G. K.; Duran, G. E.; Mangili, A., Beketic-Oreskovic, L.; Sikic, B. I. MDR1 activation is the predominant resistance mechanism selected by vinblastine in MES-SA cells $B r . J$. Cancer 2000, 83, 892-898.

15. Geney, R.; Ungureanu, M.; Li, D.; Ojima, I. Overcoming multidrug resistance in taxane chemotherapy. Clinical Chem. Lab. Med. 2002, 40, 918-925.

16. Hartwell, J. L. Plants used against cancer. Lloydia 1967, 30, 379-436. 
17. Martin, S. F. "The Amaryllidaceae alkaloids" In The Alkaloids; Brossi, A. R. Ed.; Academic Press: New York, 1987, 30, p. 251.

18. Hoshino, O. "The Amaryllidaceae alkaloids" In The Alkaloids Cordell, G. A. Ed.; Academic Press: London, 1998, 51, p. 323.

19. Cook, J. W.; Loudon, J. D. In The Alkaloids; Manske, R. H. F., Holmes, H. L., Eds.; Academic Press: New York, 1952, 2, Chapter 11, p. 331.

20. Ceriotti, G. Narciclasine: An antimitotic substance from Narcissus bulbs. Nature 1967, 213, 595.

21. Kornienko, A.; Evidente, A. Chemistry, biology, and medical potential of narciclasine and its congeners. Chem. Rev. 2008, 108, 1982-2014.

22. Liu, J.; Hu, W. X.; He, L. F.; Ye, M.; Li, Y. Effects of lycorine on HL-60 cells via arresting cell cycle and inducing apoptosis. FEBS Letters 2004, 578, 245-250.

23. Liu, J.; Li, Y.; Tang, L. J.; Zhang, G. P.; Hu, W. X. Treatment of lycorine on SCID mice model with human APL cells. BioMed. Pharmacother. 2007, 61, 229-234.

24. Liu, X. S.; Jiang, J.; Jiao, X. Y.; Wu, Y. E.; Lin, J. H.; Cai, Y. M. Lycorine induces apoptosis and down-regulation of MCL-1 in human leukemia cells. Cancer Lett. 2009, 274, 16-24.

25. McLachlan, A.; Kekre, N.; McNulty, J.; Pandey S. Pancratistatin: a natural anti-cancer compound that targets mitochondria specifically in cancer cells to induce apoptosis. Apoptosis. 2005, 10, 619-630.

26. Griffin, C.; Sharda, N.; Sood, D.; Nair, J.; McNulty, J.; Pandey, S. Selective cytotoxicity of pancratistatin-related natural Amaryllidaceae alkaloids: evaluation of the activity of two new compounds. Cancer Cell. Int. 2007, 7, 10. 
27. Vshyvenko, S.; Scattolon, J.; Hudlicky, T.; Romero, A. E.; Kornienko, A.; Ma, D.; Griffin, G.; Pandey, S. Unnatural C-1 homologues of pancratistatin: Synthesis and promising biological activities. Can. J. Chem. 2012, 90, 932-943.

28. Vshyvenko, S.; Scattolon, J.; Hudlicky, T.; Romero, A. E.; Kornienko, A. Synthesis of C-1 Homologues of Pancratistatin and their Preliminary Biological Evaluation. Bioorg. Med. Chem. Lett. 2011, 21, 4750-4752.

29. Collins, J.; Rinner, U.; Moser, M.; Hudlicky, T.; Ghiviriga, I.; Romero, A. E.; Kornienko, A.; Ma, D.; Griffin, C.; Pandey, S. Chemoenzymatic Synthesis of Amaryllidaceae Constituents and Biological Evaluation of their C-1 Analogues. The Next Generation Synthesis of 7Deoxypancratistatin and trans-Dihydrolycoricidine. J. Org. Chem. 2010, 75, 3069-3084.

30. Manpadi, M.; Kireev, A. S.; Magedov, I. V.; Altig, J.; Tongwa, P.; Antipin, M. Y.; Evidente, A.; van Otterlo, W. A. L.; Kornienko, A. Synthesis of Structurally Simplified Analogues of Pancratistatin: Truncation of the Cyclitol Ring. J. Org. Chem. 2009, 74, 7122-7133.

31. Van Goietsenoven, G.; Hutton, J.; Becker, J. P.; Lallemand, B.; Robert, F.; Lefranc, F.; Pirker, C.; Vandenbussche, G.; Van Antwerpen, P.; Evidente, A.; Berger, W.; Prevost, M.; Pelletier, J.; Kiss, R.; Kinzy, T. G.; Kornienko, A.; Mathieu, V. Targeting of eEF1A with Amaryllidaceae isocarbostyrils as a strategy to combat melanomas. FASEB J. 2010, 24, 4575-4584.

32. Van Goietsenoven, G.; Andolfi, A.; Lallemand, B.; Cimmino, A.; Lamoral-Theys, D.; Gras, T.; Abou-Donia, A.; Dubois, J.; Lefranc, F.; Mathieu, V.; Kornienko, A.; Kiss, R.; Evidente, A. Amaryllidaceae Alkaloids Belonging to Different Structural Subgroups Display Activity against Apoptosis-Resistant Cancer Cells. J. Nat. Prod. 2010, 73, 1223-1227.

33. Lamoral-Theys, D.; Decaestecker, C.; Mathieu, V.; Dubois, J.; Kornienko, A.; Kiss, R.; Evidente, A.; Pottier, L. Lycorine and its Derivatives for Anticancer Drug Design. Mini-Rev. Med. Chem. 2010, 10, 41-50. 
34. Lamoral-Theys, D.; Andolfi, A.; Van Goietsenoven, G.; Cimmino, A.; Le Calvé, B.; Wauthoz, N.; Mégalizzi, V.; Gras, T.; Bruyère, C.; Dubois, J.; Mathieu, V.; Kornienko, A.; Kiss, R.; Evidente, A. Lycorine, the Main Phenanthridine Amaryllidaceae Alkaloid, Exhibits Significant Anti-Tumor Activity in Cancer Cells that Display Resistance to Proapoptotic Stimuli: an Investigation of Structure-Activity Relationship and Mechanistic Insight. J. Med. Chem. 2009, $52,6244-6256$.

35. Evdokimov, N.; Lamoral-Theys, D.; Mathieu, V.; Andolfi, A.; Pelly, S.; van Otterlo, W.; Magedov, I.; Kiss, R.; Evidente, A.; Kornienko, A. In Search of a Cytostatic Agent Derived from the Alkaloid Lycorine: Synthesis and Growth Inhibitory Properties of Lycorine Derivatives. Bioorg. Med. Chem. 2011, 19, 7252-7261.

36. Van Goietsenoven, G.; Mathieu, V.; Lefranc, F.; Kornienko, A.; Evidente, A. ; Kiss, R. Narciclasine as well as other Amaryllidaceae Isocarbostyrils are Promising GTP-ase Targeting Agents against Brain Cancers. Med. Res. Rev. 2013, 33, 439-455.

37. Dasari, R.; Banuls, L. M. Y.; Masi, M.; Pelly, S. C.; Mathieu, V.; Green, I. R.; van Otterlo, W. A. L.; Evidente, A.; Kiss, R.; Kornienko, A. C1,C2-Ether Derivatives of the Amaryllidaceae Alkaloid Lycorine: Retention of Activity of Highly Lipophilic Analogues Against ApoptosisResistant Cancer Cells. Bioorg. Med. Chem. Lett. 2014, 24,923-927.

38. Kim, Y. H.; Park, E. Y.; Park, M. H.; Badarch, U.; Woldemichael, G. M.; Beutler, J. A. Crinamine from Crinum asiaticum var. japonicum inhibits hypoxia inducible factor-1 activity but not activity of hypoxia inducible factor-2. Biol. Pharm. Bull. 2006, 29, 2140-2142.

39. Lin, L. Z.; Hu, S. F.; Chai, H. B.; Pengsuparp, T.; Pezzuto, J. M.; Cordell, G. A. Ruangrungsi, N. Lycorine alkaloids from Hymenocallis Littoralis. Phytochemistry. 1995, 40, 1295-1298. 
40. Hohmann, J.; Forgo, P.; Molnar, J.; Wolfard, K.; Molnar, A.; Thalhammer, T.; Mathe, I.; Sharples, D. Antiproliferative Amaryllidaceae alkaloids isolated from the bulbs of Sprekelia formosissima and Hymenocallis x festalis. Planta Med. 2002, 68, 454-457.

41. Furusawa, E.; Irie, H.; Combs, D.; Wildman, W. C. Therapeutic activity of pretazettine on Rauscher leukemia - comparison with the related Amaryllidaceae alkaloids. Chemotherapy. $1980,26,36-45$.

42. Weniger, B.; Italiano, L.; Beck, J. P.; Bastida, J.; Bergonon, S.; Codina, C. Lobstein, A.; Anton, R. Cytotoxic activity of Amaryllidaceae alkaloids. Planta Med. 1995, 61, 77-79.

43. Abd Eil Hafiz, M. A.; Ramadan, M. A.; Jung, M. L.; Beck, J. P.; Anton, R. Cytotoxic activity of Amaryllidaceae alkaloids from Crinum Augustum and Crinum Bulbispermum. Planta Med. 1991, 57, 437-439.

44. Likhitwitayawuid, K.; Angerhofer, C. K.; Chai, H.; Pezzuto, J. M.; Cordell, G. A. Traditional medicinal plants of Thailand. 22. Cytotoxic and antimalarial alkaloids from the bulbs of Crinum Amabile. J. Nat. Prod. 1993, 56, 1331-1338.

45. Jimenez, A.; Santos, A.; Alonso, G.; Vazquez, D. Inhibitors of protein synthesis in eukarytic cells. Comparative effects of some amaryllidaceae alkaloids. Biochim Biophys Acta 1976, 425, 342.

46. McNulty, J.; Nair, J. J.; Codina, C.; Bastida, J.; Pandey, S.; Gerasimoff, J.; Griffin, C. Selective apoptosis-inducing activity of crinum-type Amaryllidaceae alkaloids. Phytochemistry. 2007, $68,1068-1074$.

47. Nair, J. J.; Bastida, J.; Viladomat, F.; van Staden, J. Cytotoxic agents of the crinane series of Amaryllidaceae alkaloids. Nat. Prod. Rep. 2012, 7, 1677-1688.

48. Luchetti, G.; Johnston, R.; Mathieu, V.; Lefranc, F.; Hayden, K.; Andolfi, A.; Lamoral-Theys, D.; Reisenauer, M. R.; Champion, C.; Pelly, S. C.; van Otterlo, W. A. L.; Magedov, I. V.; Kiss, 
R.; Evidente, A.; Rogelj, S.; Kornienko, A. Bulbispermine: A Crinine-Type Amaryllidaceae Alkaloid Exhibiting Cytostatic Activity towards Apoptosis-Resistant Glioma Cells. ChemMedChem. 2012, 7, 815-822.

49. Schwartz, M. A.; Holton, R. A. Intramolecular Oxidative Phenol Coupling. II. A Biogenetictype Synthesis of (+-)-Maritidine. J. Am. Chem. Soc. 1970, 92, 1090-1092.

50. Kita, Y.; Takada, T.; Gyoten, M.; Tohma, H.; Zenk, M. H.; Eichorn, J. An oxidative Intramolecular Phenolic coupling reaction for the synthesis of Amaryllidaceae alkaloids using a hypervalent iodine(III) reagent. J. Org. Chem. 1996, 61, 5857-5864.

51. Pandey, G.; Gupta, N. R.; Gadre, S. R. Construction of the 5,10b-phenanthridine skeleton using $[3+2]$-cycloaddition of a non-stabilized azomethine ylide: total synthesis of maritidine and crinine alkaloids. Eur. J. Org. Chem. 2011, 740-750.

52. Kodama, S.; Takita, H.; Kajimoto, T.; Nishide, K.; Node, M. Synthesis of Amaryllidaceae alkaloids, siculine, oxocrinine, epicrinine, and buflavine. Tetrahedron. 2004, 60, 4901-4907.

53. Anwar, H. F.; Hansen, T. V. First total synthesis of (+-)-powelline. Synlett. 2008, 2681-2683.

54. Moon, B.; Han, S.; Yoon, Y.; Kwon, H. Macrocyclic lactam synthesis via a ring expansion reaction: construction of the cripowellin skeleton. Org. Lett. 2005, 7, 1031-1034.

55. Mosmann, T. Rapid colorimetric assay for cellular growth and survival - application to proliferation and cytotoxicity assays. J. Immunol. Methods. 1983, 65, $55 \square 63$.

56. Montenegro, M. F.; Moral-Naranjo, M. T.; Munoz-Delgado, E, Campoy, F. J.; Vidal C. J. Hydrolysis of acetylthiocholine, o-nitroacetanilide and o-nitrotrifluoroacetanilide by fetal bovine serum acetylcholinesterase. FEBS J. 2009, 276, 2074-2083.

57. Boger, D. L.; Yohannes, D. Total synthesis of K-13. J. Org. Chem. 1989, 54, 2498-2502. 
58. Beaumont, K.; Webster, R.; Gardner, I.; Dack, K. Design of ester prodrugs to enhance oral absorption of poorly permeable compounds: Challenges to the discovery scientist. Curr. Drug Metabol. 2003, 4, 461-485.

59. Branle, F.; Lefranc, F.; Camby, I.; Jeuken, J.; Geurts-Moespot, A.; Sprenger, S.; Sweep, F.; Kiss, R.; Salmon, I. Evaluation of the efficiency of chemotherapy in in vivo orthotopic models of human glioma cells with and without 1p19q deletions and in C6 orthotopic allografts serving for the evaluation of surgery combined with chemotherapy. Cancer 2002, 95, 641-655.

60. Lefranc, F.; Nuzzo, G.; Hamdy, N. A.; Fakhr, I.; Banuls, L. M. Y.; van Goietsenoven, G. V.; Villani, G.; Mathieu, V.; van Soest, R.; Kiss, R.; Ciavatta, M. L. In Vitro Pharmacological and Toxicological Effects of Norterpene Peroxides Isolated from the Red Sea Sponge Diacarnus erythraeanus on Normal and Cancer Cells. J. Nat. Prod. 2013, 76, 1541-1547.

61. Li, J.; Hu, W.; Lan, Q. The apoptosis-resistance in t-AUCB-treated glioblastoma cells depends on activation of Hsp27. J. Neurooncol. 2012, 110, 187-194.

62. Mathieu, A. ; Remmelink, M. ; D’Haene, N. ; Penant, S. ; Gaussin, J.F. ; Van Ginckel, R. ; Darro, F.; Kiss, R.; Salmon, I. Development of a chemoresistant orthotopic human nonsmall cell lung carcinoma model in nude mice: analyses of tumor heterogenity in relation to the immunohistochemical levels of expression of cyclooxygenase-2, ornithine decarboxylase, lungrelated resistance protein, prostaglandin E synthetase, and glutathione-S-transferase-alpha (GST)-alpha, GST-mu, and GST-pi. Cancer. 2004, 101, 1908-1918.

63. Singh, S. K.; Hawkins, C.; Clarke, I. D.; Squire, J. A.; Bayani, J.; Hide, T.; Henkelman, R. M.; Cusimano, M. D.; Dirks, B. P. Identification of human brain tumour initiating cells. Nature. 2004, 432, 396-401. 
64. Yuan, X.; Curtin, J.; Xiong Y.; Liu, G.; Waschsmann-Hogiu, S.; Black, K. L.; Yu, J. S. Isolation of cancer stem cells from adult glioblastoma multiforme. Oncogene. 2004, 23, 93929400.

65. Galli, R.; Binda, E.; Orfanelli, U.; Cipelletti, B.; Gritti, A.; De Vitis, S.; Fiocco, R.; Foroni, C.; Dimeco, F.; Vescovi, A. Isolation and characterization of tumorigenic, stem-like neural precursors from human glioblastoma. Cancer Res. 2004, 64, 7011-7021.

66. Lee, J.; Kotliarova, S.; Kotliarov, Y.; Li, A.; Su, Q.; Donin, N. M.; Pastorino, S.; Purow, B. W.; Christopher, N.; Zhang, W.; Park, J. K.; Fine, H. A. Tumor stem cells derived from glioblastomas cultured in bFGF and EGF more closely mirror the phenotype and genotype of primary tumors than do serum-cultured cell lines. Cancer Cell 2006, 9, 391-403.

67. Bao, S.; Wu, Q.; McLendon, R. E.; Hao, Y.; Shi, Q.; Hjelmeland, A. B.; Dewhirst, M. W.; Bigner, D. D.; Rich, J. M. Glioma stem cells promote radioresistance by preferential activation of the DNA damage response. Nature 2006, 444, 756-760.

68. Liu, G.; Yuan, X.; Zeng, Z.; Tunici, P.; Ng, H.; Abdulkadir, I. R.; Lu, L.; Irvin, D.; Black, K. L.; Yu, J. S. Analysis of gene expression and chemoresistance of CD133+ cancer stem cells in glioblastoma. Mol. Cancer. 2006, 5, 67.

69. Johannessen, T. C.; Bjerkvig, R.; Tysnes, B. B. DNA repair and cancer stemlike cells Potential partners in glioma drug resistance? Cancer Treat Rev. 2008, 34, 558-567.

70. Ma, S.; Lee, T. K.; Zheng, B. J.; Chan, K. W.; Guan, X. Y. CD133+ HCC cancer stem cells confer chemoresistance by preferential expression of the Akt/PKB survival pathway. Oncogene. 2008, 27, 1749-1758.

71. Weller, M.; Stupp, R.; Reifenberger, G.; Brandes, A. A.; van den Bent, M. J.; Wick, W.; Hegi, M. E. MGMT promoter methylation in malignant gliomas: ready for personalized medicine? Nat. Rev. Neurol. 2010, 6, 39-51. 
72. Mayba, O.; Gnad, F.; Peyton, M.; Zhang, F.; Walter, K.; Du, P.; Huntley, M. A.; Jiang, Z.; Liu, J.; Haverty, P. M.; Gentleman, R. C.; Li, R.; Minna, J. D.; Li, Y.; Shames, D. S.; Zhang, Z. Integrative analysis of two cell lines derived from non-small-cell lung cancer patient - a genomics approach. Pac. Symp. Biocomput. 2014, 75-86.

73. Harker, W. G.; Sikic, B. I. Multidrug (pleiotropic) resistance in doxorubicin-selected variants of the human sarcoma cell line MES-SA. Cancer Res. 1985, 45, 4091-4096.

74. Cencic, R.; Robert, F.; Pelletier, J. Identifying small molecule inhibitors of eukaryotic translation initiation. Methods Enzymol. 2007, 431, 269-302.

75. Kupchan, S. M.; Dhingra, O. P.; Kim, C. -K. Efficient intramolecular monophenol oxidative coupling. J. Org. Chem. 1978, 43, 4076-4081.

76. Gunther, H. S.; Schmidt, N. O.; Philips, H. S.; Kemming, D.; Kharbanda, S.; Soriano, R.; Modrusan, Z.; Meissner, H.; Westphal, M.; Lamszus, K. Glioblastoma-derived stem cellenriched cultures form distinct subgroups according to molecular and phenotypic criteria. Oncogene 2008, 27, 2897-2909.

77. Bliss, C. I. Toxicity of Poisons. Annal. Appl. Biol. 1939, 26, 585-587.

TOC:

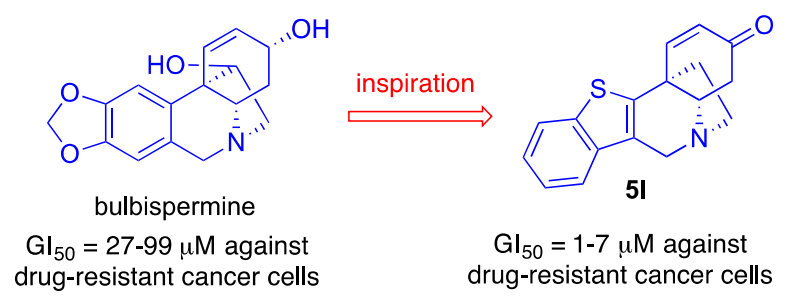

